\title{
Micronekton distribution as influenced by mesoscale eddies, Madagascar shelf and shallow seamounts in the south-western Indian Ocean: An acoustic approach
}

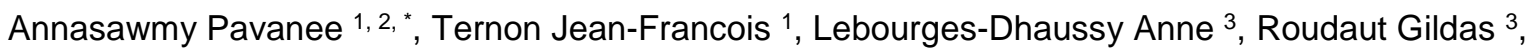 \\ Cotel Pascal ${ }^{1}$, Herbette Steven ${ }^{4}$, Ménard Frédéric ${ }^{5}$, Marsac Francis ${ }^{1,2}$
}

\author{
${ }^{1}$ MARBEC, Univ. Montpellier, CNRS, Ifremer, IRD, Sète, France \\ 2 Department of Biological Sciences and Marine Research Institute/ICEMASA, University of Cape Town, \\ Cape Town, South Africa \\ 3 LEMAR, IRD, UBO, CNRS, Ifremer, Plouzané, France \\ ${ }^{4}$ Laboratoire d'Océanographie Physique et Spatiale (LOPS), IUEM, Univ. Brest, CNRS, Ifremer, IRD, \\ Brest, France \\ ${ }^{5}$ Aix Marseille Univ., Université de Toulon, CNRS, IRD, MIO, Marseille, France \\ * Corresponding author : Pavanee Annasawmy, email address : angelee-pavanee.annasawmy@ird.fr
}

\begin{abstract}
:
An investigation of the vertical and horizontal distributions of micronekton, as influenced by mesoscale eddies, the Madagascar shelf and shallow seamounts, was undertaken using acoustic data collected during two research cruises at an unnamed pinnacle (summit depth $\sim 240 \mathrm{~m}$ ) thereafter named "MADRidge", and at La Pérouse seamount $(\sim 60 \mathrm{~m})$ in the south-western Indian Ocean. MAD-Ridge is located to the south of Madagascar, in an "eddy corridor", known both for its high mesoscale activity and high primary productivity. In contrast, La Pérouse is located on the outskirts of the Indian South Subtropical Gyre (ISSG) province, characterised by low mesoscale activity and low primary productivity. During the MAD-Ridge cruise, a dipole was located in the vicinity of the seamount, with the anticyclone being almost stationary on the pinnacle. Total micronekton acoustic densities were greater at MAD-Ridge than at La Pérouse. Micronekton acoustic densities of the total water column were lower within the anticyclone than within the cyclone during MAD-Ridge. Micronekton followed the usual diel vertical migration (DVM) pattern, except within the cyclone during MAD-Ridge where greater acoustic densities were recorded in the daytime surface layer. The backscatter intensities were stronger at the $38 \mathrm{kHz}$ than at the 70 and $120 \mathrm{kHz}$ frequencies in the daytime surface layer at MAD-Ridge cyclonic stations. These backscatter intensities likely correspond to gas-filled swimbladders of epi- and mesopelagic fish actively swimming and feeding within the cyclone or gelatinous organisms with gas inclusions. Our findings evidenced that the distributions of micronekton and DVM patterns are complex and are influenced significantly by physical processes within mesoscale eddies. The mesoscale eddies' effects were dominant over any potential seamount effects at the highly dynamic environment prevailing at MAD-Ridge during the cruise. No significant increase in total micronekton acoustic densities was observed over either seamount, but dense aggregations of biological scatterers were observed on their summits during both day and night.
\end{abstract}


Keywords: Micronekton, Diel vertical migration, Mesoscale eddies, Madagascar shelf, Seamount, South-western indian ocean 
Features such as mesoscale cyclonic and anticyclonic eddies, upwelling events, tidal fronts, shelves, seamounts and river runoff play a significant role in regional ecosystems (Bakun, 2006; Mann and Lazier, 2006; Benitez-Nelson and McGillicuddy, 2008). Mesoscale cyclonic and anticyclonic eddies are ubiquitous in the world's oceans (Chelton et al., 2011). They have time-scales of approximately 10-30 days and horizontal scales between 10 and $100 \mathrm{~km}$ (Mann and Lazier, 2006; Chelton et al., 2011). In oligotrophic systems, eddies are important features because they provide mechanisms whereby the physical energy of the ocean is converted to trophic energy to support biological processes (Bakun, 2006; Godø et al., 2012). Cyclonic eddies, through upwelling of nutrients in their centres from deeper layers to the euphotic zone, are usually known to enhance local productivity (Owen, 1980, 1981; McGillicuddy and Robinson, 1997; McGillicuddy et al., 1998; Klein and Lapeyre, 2009; Huggett, 2014; Singh et al., 2015). Anticyclonic eddies may promote the development of frontal structures (Bakun, 2006). In anticyclones, highly productive waters may be entrained laterally from nearby regions to the eddy periphery or upwelling of nutrients may occur along the eddy boundary (McGillicuddy, 2016). At the frontier between eddies, smaller-scale or submesoscale features (elongated filaments with a $10-\mathrm{km}$ width) have been reported to enhance nutrient supply and primary productivity in oligotrophic conditions (Lévy et al., 2001, 2018; Klein and Lapeyre, 2009). Biological responses to eddies, however, are complex and depend on a range of factors including seasonal modulation of the mixed layer depth (Dufois et al., 2014), timing, magnitude and duration of nutrient input and also on eddy properties such as the formation, intensity, age and eddy-induced Ekman pumping (BenitezNelson and McGillicuddy, 2008).

Continental shelves and seamounts are also features that may lead to enhanced productivity when certain conditions are met. Upwelling regions south of Madagascar have been observed 
to be biological hotspots with increased productivity (Raj et al., 2010; Ramanantsoa et al., 2018) and increased acoustic biomass estimates of pelagic fish and whale sightings (Pripp et al., 2014). Phytoplankton types may also differ between continental shelves and ocean basins, with shelf areas exhibiting larger phytoplankton cells because of the processes leading to high nutrient concentrations in the euphotic zone and cells rapidly take up nutrients (Nishino et al., 2011). Seamounts are ubiquitous features of the world's oceans and have been reported to influence the prevailing ocean currents (Royer, 1978; White et al., 2007), creating various local dynamic responses such as formation of a Taylor column, isopycnal doming (Mohn and Beckmann, 2002), enclosed circulation cell (White et al., 2007), upwelling, vertical mixing of nutrient-rich waters and enhanced productivity (Boehlert and Genin, 1987; Genin, 2004). In a nutrient-limited environment like the south-western Indian Ocean, processes injecting nutrients into the euphotic zone (such as mesoscale features, seamounts, coastal upwelling events and river runoff) are likely to modulate the chlorophyll $a$ signature by increasing phytoplankton growth, attracting a range of secondary and tertiary consumers such as zooplankton and micronekton.

Mesopelagic micronekton are actively swimming organisms that typically range in size from 2 to $20 \mathrm{~cm}$. They include diverse taxonomic groups (De Forest and Drazen 2009) such as crustaceans (adult euphausiids, pelagic decapods and mysids), cephalopods (small species and juvenile stages of large oceanic species) and fish (mainly mesopelagic species and juveniles of other fish) (Brodeur et al., 2005; Brodeur and Yamamura 2005; Ménard et al., 2014). Gelatinous organisms are under-represented components of the mesopelagic community (Lehodey et al., 2010; Kloser et al., 2016). Micronekton are important in the energy transfer to higher trophic levels because they are preyed upon by various top marine predators (Guinet et al., 1996; Bertrand et al., 2002; Potier et al., 2007; Cherel et al., 2010; Danckwerts et al., 2014; Jaquemet et al., 2014). They also transport energy to deeper regions of the ocean via respiration, excretion and natural mortality (Hidaka et al., 2001; Catul et al., 
2011; Bianchi et al., 2013). This energy transport is made possible by the extensive diel vertical migration (DVM) patterns of some micronekton species, with the organisms migrating to the upper $200 \mathrm{~m}$ of the water column at dusk and below $400 \mathrm{~m}$ at dawn (Lebourges-Dhaussy et al., 2000; Béhagle et al., 2014; Annasawmy et al., 2018). Diel vertical migration is believed to result from a compromise between the need to feed and to avoid predation (Heywood, 1996), with light being the main controlling factor in initiating ascent and descent (Heywood, 1996; Andersen et al., 1998; Brierley, 2014). The distribution of micronekton communities across ocean basins is not uniform (Judkins and Haedrich, 2018). Some studies have reported higher biomasses of micronekton scattering layers at seamount flanks and summits relative to the surrounding ocean, e.g. the Emperor (265m, Boehlert, 1988) and Cross seamounts in the Pacific (330 m, Johnston et al., 2008); Condor (182-214 m) and Gigante (161 m) seamounts in the Azores (Cascão et al., 2017).

At the ocean-basin scale, the western side of the oligotrophic Indian South Subtropical Gyre (ISSG) biogeochemical province (Longhurst, 2007) holds reduced micronekton abundances and acoustic densities relative to the dynamic and more productive East African Coastal (EAFR) province (Annasawmy et al., 2018). Within the ISSG and EAFR provinces, features such as eddies, coastal upwelling at the Madagascar shelf and seamounts may further impact the local productivity, resulting in significant variability in micronekton distributions via bottom-up processes. This paper investigates the influence of mesoscale eddies, the South Madagascar shelf and two shallow seamounts, La Pérouse and an unnamed pinnacle on the Madagascar Ridge, hereafter called "MAD-Ridge", in shaping micronekton vertical and horizontal distributions by combining data from ship-based platforms (acoustics, current profiler and CTD) and satellite altimetry.

\section{Material and Methods}


105 Two research surveys were carried out on board the RV Antea at La Pérouse $\left(19^{\circ} 43^{\prime} S\right.$ and $54^{\circ} 10^{\prime} \mathrm{E}$ ) and MAD-Ridge seamounts $\left(27^{\circ} 29^{\prime} \mathrm{S}\right.$ and $\left.46^{\circ} 16^{\prime} \mathrm{E}\right)$. La Pérouse (summit depth 60 $\mathrm{m}$ ) is located along the north-western boundary of the ISSG province and MAD-Ridge (summit depth $\sim 240 \mathrm{~m}$ ) is located on the southern boundary of the EAFR (Fig. 1a). The La Pérouse cruise (DOI: 10.17600/16004500) investigated the area within 10-18 km around the seamount from the 15 to 30 September 2016 (Fig. 1b). The MAD-Ridge Leg 1 cruise (DOI: $10.17600 / 16004800)$ was divided into a West-East transect (248 km long from hydrographic station 1 to 15 ) and a South-North transect (292 km long from hydrographic station 16 to 31) and took place from the 8 to 24 November 2016 (Fig. 2).

\subsection{Satellite data}

The mesoscale eddy field during both the La Pérouse and MAD-Ridge cruises were described using daily delayed-time Absolute Dynamic Topography (ADT) with $1 / 4^{\circ}(\sim 25 \mathrm{~km})$ spatial resolution. Delayed-time ADT was produced and distributed by the Copernicus Marine

(CMEMS) and available at http://marine.copernicus.eu/, from which absolute geostrophic currents have been calculated and used to derive dynamic parameters (see next section). Delayed-time Mean Sea Level Anomalies (MSLA) data, with $1 / 4^{\circ}(\sim 25 \mathrm{~km})$ spatial resolution in the vicinity of MAD-Ridge seamount were also downloaded from http://marine.copernicus.eu/, and used for direct eddy field representation. 
The $12 \mathrm{kHz}$ frequency of a Simrad EA500 echosounder was used to acquire a detailed

127 bathymetry of the seamounts. The bathymetry data were interpolated on a regular grid using the Golden Surfer (C) software (version 10.3.705).

\subsubsection{Hydrographic stations}

A Sea-Bird 911+ CTD rosette system equipped with a Wetlabs ECO FL fluorometer was used to profile temperature, fluorescence and dissolved oxygen from the surface to a depth of 1000 m during the La Pérouse and MAD-Ridge cruises. Discrete samples of chlorophyll $a$ measured by high pressure liquid chromatography was used to calibrate the fluorescence sensor of the CTD during both cruises and to determine the depth range where the maximum chlorophyll $a$ values (Fmax) were found. The integrated chlorophyll $a$ concentrations

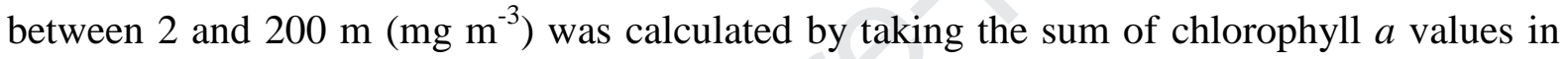
that depth range. The average depths of the thermocline were assessed from the CTD profiles using the $20^{\circ} \mathrm{C}$ isotherm depth as a proxy.

Two $300 \mathrm{kHz}$ RDI (upward and downward-looking) L-ADCP current profilers attached to the CTD frame were used to investigate the vertical structure of the current field during both cruises. The S-ADCP data were collected with a $75 \mathrm{kHz}$ RDI Ocean Surveyor II. As L-ADCP data were missing at MAD-Ridge stations 2 and 3, S-ADCP data were used instead. The LADCP data were collected to a depth of $1000 \mathrm{~m}$ whereas the S-ADCP data were collected to a depth of $600 \mathrm{~m}$. Both datasets showed strong correlations which allowed the use of the Lwith the S-ADCP (Vianello et al., 2020). For each hydrographic station, the average current speed (in $\mathrm{cm} \mathrm{s}^{-1}$ ) over the depth range 104-304 m, was calculated from the west-east zonal $(u)$ and south-north meridional $(v)$ velocity components measured by the S-ADCP or L148 ADCP.

A classification of MAD-Ridge hydrographic stations (numbered 1-31, Fig. 2) was performed based on their location relative to the mesoscale eddies (cyclonic, anticyclonic, interface 
151 between the dipole), to the seamount (summit or flank, both within the anticyclonic eddy) and

152 to the Madagascar shelf. This classification was based on the hydrology (temperature-salinity 153 profiles) of each station and a standard dynamical parameter, the Okubo-Weiss parameter, $W$ 154 (Okubo, 1970; Weiss, 1991; Isern-Fontanet et al., 2004). The latter is calculated from 155 equation 1 below, where $S_{n}$ is the normal strain, $S_{S}$ the shear strain, $\omega$ the relative vorticity, 156 and $u$ and $v$ (Eq. 2 below) are the surface geostrophic velocity zonal and meridional 157 components derived from the absolute dynamic topography (altimetry). The Okubo-Weiss 158 parameter allows the separation of the flow into a vorticity-dominated region $\left(W<-W_{0}\right)$ and 159 a strain-dominated region $\left(W>-W_{0}\right)$, with $W_{0}=0.2 \sigma_{\mathrm{W}},\left(\sigma_{\mathrm{W}}\right.$ being the standard deviation of 160 $W$ over the whole domain) (Isern-Fontanet et al., 2004). It has been used widely in the southwestern Indian Ocean by Halo et al. (2014) to distinguish the core of eddies ( $\left.W>-W_{0}\right)$ from the periphery of eddies $\left(W<-W_{0}\right)$ and is given by:

where:

$165 \quad S n=\frac{\partial u}{\partial x}-\frac{\partial v}{\partial y}, S_{S}=\frac{\partial v}{\partial x}+\frac{\partial u}{\partial y}, \omega=\frac{\partial v}{\partial x}-\frac{\partial u}{\partial y}$ Eq. 2

However, $W$ values have to be used cautiously against in situ data because the spatial resolution of the altimetry is low $(\sim 25 \mathrm{~km})$ relative to each station. Therefore, for each station, the altimetry data were complemented by the available in situ data such as sea surface temperature and salinity obtained from a ship-mounted thermosalinograph and dissolved oxygen obtained from the CTD. This combined set of information allowed us to segregate the stations into different categories (see example for stations 3, 5 and 13, Supplementary Material, Fig. 1 and Supplementary Material, Table 1). 
Daytime zooplankton samples were collected with a $200-\mu \mathrm{m}-\mathrm{mesh}$ oblique Bongo net towed at a speed of 1-2 knots to a maximum depth of $200 \mathrm{~m}$ during the La Pérouse cruise $\left(0.28 \mathrm{~m}^{2}\right.$ mouth area). A $200-\mu \mathrm{m}$-mesh oblique Multinet was towed to a maximum of $200 \mathrm{~m}$ during the MAD-Ridge cruise $\left(0.25 \mathrm{~m}^{2}\right.$ mouth area) (Noyon et al., 2020). Samples from both cruises were emptied into a $200 \mu \mathrm{m}$ sieve, poured into sampling jars with filtered seawater and stored in $4 \%$ buffered formaldehyde at room temperature on board before being analysed using a Hydroptic Zooscan following the protocols in Gorsky et al. (2010). Detailed zooplankton sampling and analyses were investigated in Noyon et al. (2020).

\subsubsection{Acoustic sampling}

A Simrad EK60 echosounder operating at four frequencies was used during both the La Pérouse and Leg 1 of the MAD-Ridge cruises: $38 \mathrm{kHz}$ at $1000 \mathrm{~W}$ transmitted power, $70 \mathrm{kHz}$ (acquired range of $500 \mathrm{~m}$ ) at $750 \mathrm{~W}, 120 \mathrm{kHz}(250 \mathrm{~m})$ at $200 \mathrm{~W}$ and $200 \mathrm{kHz}(150 \mathrm{~m})$ at 90 W. The water column was correctly sampled to a depth of $735 \mathrm{~m}$ during data acquisition for the $38 \mathrm{kHz}$ frequency of the La Pérouse cruise, with data being of poor quality below that depth. For comparison with the La Pérouse cruise, echo-integrated acoustic data for the 38 $\mathrm{kHz}$ frequency of the MAD-Ridge cruise has also been selected down to $735 \mathrm{~m}$ in this study. The pulse duration was set at $0.512 \mathrm{~ms}$. The transducers were calibrated prior to both cruises following the procedures recommended in Foote et al. (1987). MAD-Ridge acoustic data were collected along the West-East and South-North transects (Fig. 2) at a vessel speed of 8-9 knots. Additional transects were also conducted during the day and night in close proximity to the MAD-Ridge summit and flanks at vessel speeds of 8-9 knots (Supplementary Material, Fig. 2).

The Matecho software (an open source IRD tool computed with MATLAB 7.11.0.184, Release 2010b- and based on the IFREMER's Movies3D software; Trenkel et al., 2009; Perrot et al., 2018) was used to process and visualize acoustic data from both cruises. 
Background, transient and impulsive noises along with attenuated signals (Perrot et al., 2018)

200 were removed using the algorithms designed in De Robertis and Higginbottom (2007) and

201

202

203

204

205

206

207

208

209

210

211

212

213

214

215

216

217

218

219

220

221

222

223

Ryan et al. (2015). An offset of $10 \mathrm{~m}$ below the sea surface was applied to account for the acoustic detection of the surface turbulence. During both cruises, echo-integration of the acoustic data was performed on 1-m layers at an elementary sampling distance unit of 0.1 nmi (nautical mile) and at a threshold of $-80 \mathrm{~dB}$ to exclude scatterers (entities contributing to the backscattered energy) not representative of the micronekton community (Béhagle et al., 2017). The micronekton acoustic density was determined by the nautical area scattering coefficient NASC $\left(\mathrm{s}_{\mathrm{A}}, \mathrm{m}^{2} \mathrm{nmi}^{-2}\right)$, related to the backscattered energy (MacLennan et al., 2002). NASC can be used as a proxy of the relative biomass of micronekton provided assumptions that the composition of scattering layers and the resulting scattering properties of micronekton are relatively homogeneous (Béhagle et al., 2014). The volume backscattering strength $\left(\mathrm{S}_{\mathrm{V}}, \mathrm{dB}\right.$ re $1 \mathrm{~m}^{-1}$; MacLennan et al., 2002) was also calculated for each frequency (38 $\mathrm{kHz}, 70 \mathrm{kHz}$ and $120 \mathrm{kHz}$ ) to obtain the relative acoustic density of scatterers per unit volume and was used to generate Red Green Blue (RGB) composite images (see next section). The water column at the $38 \mathrm{kHz}$ frequency was separated into the following depth categories, based on epipelagic and mesopelagic layers: surface (10-200 m), intermediate (200-400 m), deep (400-735 m) and total water column (10-735 m). Diurnal and nocturnal periods were assessed using Matecho software through visual analysis of the echograms.

\subsection{Data visualisation}

Vertical distributions of the environmental descriptors (current speed, temperature and chlorophyll $a$ ) were mapped from the surface to $~ 1000 \mathrm{~m}$ (except for chlorophyll) along the west-east and south-north transects of MAD-Ridge Leg 1 (Fig. 3a, b) using the Section mode of the software Ocean Data View (ODV, version 4.5.7; Schlitzer, 2013). The chlorophyll $a$ data were only mapped from the surface to $300 \mathrm{~m}$ because values were below the minimum 

level of detection deeper than that (Fig. 3c). Data interpolation between sampling stations

225 was carried out using the DIVA (Data-Interpolating Variational Analysis) gridding option in 226 ODV that spatially interpolates observations on a regular grid in an optimal way by taking 227 into account coastlines and bathymetric features to structure and divide the domain on which estimations are performed.

229 Acoustic data were represented using RGB colour coding. RGB composite images were generated in MATLAB (version 2016) based on the $38 \mathrm{kHz}, 70 \mathrm{kHz}$ and $120 \mathrm{kHz}$ echointegrated acoustic data of selected transects during the MAD-Ridge and La Pérouse cruises. The 38, 70 and $120 \mathrm{kHz}$ echo-integrated acoustic data were given in red, green and blue colour codes respectively on each RGB plot, with the dynamic of the $S_{\mathrm{V}}$ values in $\mathrm{dB}$ for each frequency being converted in 256 (0-255) levels of each colour. A linear transformation of the backscatter was applied to each frequency (fr):

Colour index $(\mathrm{fr})=[255 /($ High scale threshold- Low scale threshold $)] \times\left[\mathrm{S}_{\mathrm{V}}(\mathrm{fr})-\right.$ Low scale threshold], Eq. 3

where the high and low scale thresholds are the maximum and minimum backscatter for hue visualisations, respectively. $\mathrm{S}_{\mathrm{V}}(\mathrm{fr})$ is the backscatter value at each frequency. This acoustic visualisation technique is useful in determining the relative contribution of each frequency to the overall backscatter (red means that Sv 38 is dominant, and similarly for green and blue, Sv 70 and Sv 120 are respectively dominant) and to identify dense aggregations of scatterers (Sv 38, Sv 70 and Sv 120 all dominant and seen as "white patches"). On a RGB composite image based on the 38,70 and $120 \mathrm{kHz}$ frequencies, a dark red colour indicates a dominant but low $38 \mathrm{kHz}$ backscatter, whereas a light red colour indicates a dominant but high $38 \mathrm{kHz}$ backscatter. The same rule applies to the green $(70 \mathrm{kHz})$ and blue $(120 \mathrm{kHz})$ hues. Kloser et al. (2002) used a similar approach, but the composite image was produced by assigning a 
248 separate colour palette to each frequency (12,38 and $120 \mathrm{kHz})$ and dynamically optimising

249 the frequencies to highlight the amplitude differences in the echogram.

250

2.5 Statistical analyses

251 Kruskal Wallis tests and pairwise Wilcoxon rank sum tests were performed to assess the

252 differences in integrated chlorophyll $a$ concentrations between classified hydrographic

253 stations. In order to cover the largest depth range, day and night acoustic transects at $38 \mathrm{kHz}$

254 frequency were further selected to investigate the micronekton acoustic densities in close

255 proximity to the summits and flanks of the pinnacles (see Supplementary Material Fig. 2). As

256 the $38 \mathrm{kHz}$ frequency data did not follow a normal distribution, non-parametric Wilcoxon

257 rank sum tests were performed to compare the overall acoustic densities in each of the depth

258 categories (surface, intermediate and deep) between La Pérouse and MAD-Ridge seamounts,

259 and between day and night. Daytime acoustic density estimates representing the vertical

260 distribution of micronekton across the depth categories (surface: 10-200 m; intermediate:

261 200-400 m; deep: 400-735 m; total water column: 10-735 m) and averaged over $0.4 \mathrm{nmi}$ on

262 each side of the classified stations during MAD-Ridge cruise were investigated using non-

263 parametric Kruskal-Wallis (KW) tests and pairwise Wilcoxon rank sum tests. All statistical

264 tests were performed with version 3.3.1 of the R package.

2652.6 Taylor column theoretical calculation

266 The following non-dimensional factors were used to determine the likelihood of a Taylor

267 column formation over La Pérouse and MAD-Ridge summits (White et al., 2007), depending 268 on the mean water stratification, the mean flow field, the latitude (earth's rotation effect) and

269 the shape of the seamount:

270 (1) The Rossby number, Ro, with Ro $=\frac{U}{f \times L}$, 

where $\mathrm{U}$ is the typical flow speed $\left(0.3 \mathrm{~m} \mathrm{~s}^{-1}\right.$ at La Pérouse and $0.5 \mathrm{~m} \mathrm{~s}^{-1}$ at MAD-Ridge);

$272 f=2 * \Omega * \sin \left(\right.$ latitude), where $\Omega$ is Earth's angular velocity at 0.0000729 rads s ${ }^{-1}$; the $\sin ($ latitude) is $\sin (19.72)$ at La Pérouse and $\sin (27.48)$ at MAD-Ridge; and L is the average width of the seamounts (10 $000 \mathrm{~m}$ for La Pérouse and $27500 \mathrm{~m}$ for MAD-Ridge). Ro estimates were calculated at 0.27 at La Pérouse and 0.17 at MAD-Ridge.

(2) The relative height of the seamount $\left(\mathrm{h}_{0}\right)$ to water depth $(\mathrm{H})$, with $\alpha=\frac{h 0}{H}$,

where $\alpha$ was calculated at 0.99 at La Pérouse and 0.85 at MAD-Ridge.

(3) A combination of Ro and $\alpha$ gives the blocking parameter $B l$ (where $B l=\frac{\alpha}{R o}$ ),

which controls the formation of a Taylor column (White et al., 2007). A $B l$ value of 3.66 was calculated at La Pérouse and 4.88 at MAD-Ridge. According to Chapman and Haidvogel (1992), for seamounts taller than $\alpha \approx 0.4$, true Taylor caps will form if Ro $<0.15$ and $B l>\sim 2$ for Gaussian-shaped seamounts with moderate stratification. According to the authors, Taylor cones will not form if the Rossby number exceeds the upper bound of 0.15-0.2.

\section{Results}

3.1 Synoptic ocean circulation during the MAD-Ridge cruise

A cyclonic/anticyclonic eddy dipole was encountered along the West-East transect (hydrographic stations 1-15) of Leg 1 of the MAD-Ridge cruise, whereas the South-North transect (hydrographic stations 16-31) was mostly located inside the anticyclonic eddy and reached the Madagascar shelf (Fig. 2). Along the West-East transect, at hydrographic station 5, a sharp front was observed in the sea surface temperature and salinity data collected from the ship-mounted thermosalinograph, indicating the transition between cyclonic and anticyclonic circulations (Supplementary Material, Fig. 1). This transition area coincided with the largest current velocity recorded at the surface $\left(158 \mathrm{~cm} \mathrm{~s}^{-1}\right)$ and in the depth layer 

transects (Fig. 3a).

297

MAD-Ridge hydrographic stations were divided into six categories, according to whether

298

299 they belonged to the cyclonic eddy (C: stations 2, 3, 4), anticyclonic eddy (AC: stations 1013, 16-19, 24, 25), dipole interface (Dipole I.: station 5), seamount summit and anticyclonic eddy (Summit/AC: stations 8, 21, 22), seamount flank and anticyclonic eddy (Flank/AC: stations 7, 9, 20, 23) and shelf (Shelf: stations 30, 31). The other hydrographic stations 1, 6, $14,15,26-29$ could not be accurately resolved using the criteria mentioned in Section 2.3.1 and Supplementary Material Fig. 1, and were not assigned to any of the listed categories.

3.2 Hydrography and chlorophyll concentration during the MAD-Ridge cruise

Surface temperatures among the station categories varied between $23.7^{\circ} \mathrm{C}$ (cyclonic station 4 ) and $24.9^{\circ} \mathrm{C}$ (Summit/AC station 21). The cyclonic and shelf stations were characterised by a shallower thermocline (79-165 m and 97-117 m, respectively) than the anticyclonic stations. The anticyclonic, Summit/AC and Flank/AC stations were characterised by a relatively deeper thermocline (159-219 m, 206-209 m and 181-212 m, respectively) (Fig. 3b). Fmax values of $0.35-0.38 \mathrm{mg} \mathrm{m}^{-3}$ and $0.62-0.74 \mathrm{mg} \mathrm{m}^{-3}$ were recorded at the cyclonic and shelf stations respectively, at depths of 54-122 $\mathrm{m}$ and $56-73 \mathrm{~m}$, respectively (Fig. 3c). The anticyclonic, Summit/AC and Flank/AC stations had deeper Fmax depths (82-129 m, 131$153 \mathrm{~m}$ and 101-144 m) relative to the cyclonic and shelf stations, with Fmax values of 0.16$0.30 \mathrm{mg} \mathrm{m}^{-3}, 0.25-0.31 \mathrm{mg} \mathrm{m}^{-3}$ and $0.17-0.33 \mathrm{mg} \mathrm{m}^{-3}$, respectively. Integrated chlorophyll $a$ concentrations were statistically different between the classified hydrographic stations (KW, $\mathrm{H}=7.59, \mathrm{p}<0.05$ ), especially between the cyclonic and anticyclonic stations (pairwise comparisons, $\mathrm{p}<0.05$ ). The mean \pm S.D (standard deviation) integrated chlorophyll $a$ concentrations between 2 and $200 \mathrm{~m}$ were estimated at $29.1 \pm 7.3 \mathrm{mg} \mathrm{m}^{-3}$ and $19.3 \pm 2.1 \mathrm{mg}$ $\mathrm{m}^{-3}$ within the cyclonic and anticyclonic eddies respectively. 


\section{West-East Transect}

322 The daytime total micronekton acoustic densities of the $38 \mathrm{kHz}$ echosounder frequency 323 exhibited a decreasing trend along the West-East transect, with the greatest responses

324 recorded across stations 1-2 within the cyclonic eddy during Day_I (Fig. 4, Supplementary

Material Table 2). The lowest acoustic responses were recorded across the Summit/AC station 8 during Day_III and stations $13-15$ at the eastern periphery of the anticyclonic circulation during Day_V. The night-time total micronekton acoustic densities were greater than the daytime acoustic responses and also exhibited a decreasing trend along the WestEast transect. The greatest acoustic densities were recorded during Night_I between cyclonic stations 3 and 4 and the lowest densities were recorded during Night_IV between stations 12 and 13 at the anticyclonic periphery (Fig. 4). Differences of $1536 \mathrm{~m}^{2} \mathrm{nmi}^{-2}, 1297 \mathrm{~m}^{2} \mathrm{nmi}^{-2}$, $1058 \mathrm{~m}^{2} \mathrm{nmi}^{-2}$ and $595 \mathrm{~m}^{2} \mathrm{nmi}^{-2}$ in the micronekton acoustic responses were recorded between Night_I-Day_I, Night_II-Day_II, Night_III-Day_III and Night_IV-Day_IV, respectively. Interestingly, the surface layer gathered higher percentage acoustic densities than the deep layer during Day_I (stations 1-2), Day_II (Stations 4-6) and Day_III (stations 7-9), whereas the deep layer showed greater percentage acoustic densities than the surface layer during Day_IV and Day_V (Fig. 4). The surface layer at night displayed greater acoustic densities than the deep layer from Night_I to Night_IV (Fig. 4, Supplementary Material Table 2). The intermediate layer displayed the lowest percentage acoustic responses (1-10\%) during day and night.

The echogram of the $38 \mathrm{kHz}$ frequency showed organisms aggregating on the summits of deep topographic features labelled $\mathrm{X}$ and $\mathrm{Y}$ between 300 and $500 \mathrm{~m}$ and on the MAD-Ridge summit (Fig. 5). These organisms contributed to the higher acoustic densities within the intermediate layer at Night_II relative to the intermediate layer across other transects. This 
346 sunrise and forming a dense aggregation between 400 and $600 \mathrm{~m}$ between the deep

347 topographic feature Y and MAD-Ridge seamount (Fig. 5). Micronekton assemblages at the

348 MAD-Ridge summit has been investigated in more detail in Annasawmy et al. (2019) and

349 Cherel et al. (2020).

350 RGB composite images showed a dominant and strong $38 \mathrm{kHz}$ backscatter (red colour dominating RGB plot) between $\sim 20$ and $70 \mathrm{~m}$ across the cyclonic stations 2 and 3 during daytime and between $\sim 20$ and $120 \mathrm{~m}$ across the cyclonic stations 3 and 4 during night time and sunrise (Fig. 6). Between the anticyclonic stations 10 to 12 and across stations 13 and 15, the backscatter of the $38 \mathrm{kHz}$ frequency was dominant but lower between $\sim 20$ and $80 \mathrm{~m}$ compared to the cyclonic stations. At these anticyclonic stations, the dominant and stronger $120 \mathrm{kHz}$ backscatter between $\sim 80$ and $140 \mathrm{~m}$ during daytime matches the Fmax depth of 82 and $129 \mathrm{~m}$.

\section{$\underline{\text { South-North transect }}$}

The total daytime acoustic densities of the $38 \mathrm{kHz}$ echosounder frequency across the South-

North transect were greater during Day_VI at the southern boundary of the anticyclone, decreased during Day_VII and Day_VIII along the summit/flanks and within the anticyclone, before increasing at the northern periphery of the anticyclone during Day_IX and at the shelf station 30 during Day_X (Fig. 7, Supplementary Material Table 3). The night time acoustic responses followed the same pattern as the daytime acoustic densities along the South-North transect, with the greatest responses across Night_VI at the southern periphery of the anticyclone and Night_IX at its northern boundary (Supplementary Material, Table 3). The lowest responses along the South-North transect were recorded across Night_VII and

Night_VIII over the summit and within the anticyclone. Differences of $1559 \mathrm{~m}^{2} \mathrm{nmi}^{-2}, 1132$ $\mathrm{m}^{2} \mathrm{nmi}^{-2}, 1071 \mathrm{~m}^{2} \mathrm{nmi}^{-2}$ and $1719 \mathrm{~m}^{2} \mathrm{nmi}^{-2}$ in the micronekton acoustic densities were 

recorded between Night_VI-Day_VI, Night_VII-Day_VII, Night_VIII-Day_VIII and

371 Night_IX-Day_IX respectively. In contrast with Day_I, Day_II and Day_III along the West-

372 East transect, the percentage micronekton acoustic responses at the $38 \mathrm{kHz}$ echosounder 373 frequency in the surface layer during the day was lower than that in the deep layer across all 374 stations, except at the summit station during Day_VIII (Fig. 7). Across Night_VI to 375 Night_IX, the surface layer gathered greater micronekton acoustic responses compared to the 376 deep layer (Fig. 7, Supplementary Material, Table 3). Similar to the West-East transect, the 377 intermediate layer along the South-North transect gathered the lowest percentage 378 micronekton acoustic responses (4-11\%) both during the day and night.

RGB composite images showed a dominant and relatively high $38 \mathrm{kHz}$ backscatter between 20-100 m across stations 21, 22, 23 (on the summit and flank, within the anticyclone) and shelf stations 30 and 31 (Fig. 8). The $120 \mathrm{kHz}$ backscatter was dominant between $\sim 100$ and $140 \mathrm{~m}$, corresponding with Fmax depths ranging from 116 to $138 \mathrm{~m}$ at these stations. Across the shelf, the $120 \mathrm{kHz}$ backscatter was dominant between 60 and $80 \mathrm{~m}$, corresponding to Fmax depths of 56 to $73 \mathrm{~m}$ at these stations. Regions of high $\mathrm{S}_{\mathrm{V}}$ can be observed on the MAD-Ridge seamount (seen as "white patches" at 150-250 m on the RGB composite image between CTD stations 21 and 22), corresponding to aggregations of scatterers on the seamount summit (Fig. 8).

Median micronekton acoustic densities in the total water column and in the surface layer were the highest within the cyclonic eddy compared to any other station categories $(\mathrm{p}<0.05)$ (Fig. 9a). The Flank/AC stations showed higher median micronekton acoustic densities of the total water column compared to the Summit/AC stations (Fig. 9a). The Summit/AC stations exhibited higher median micronekton acoustic densities in the surface layer compared to the 
layer had the same overlapping ranges across all station categories except over the

396 Summit/AC stations $(\mathrm{p}<0.05)$. Station 18 , which was conducted at sunset (Table 1), within

397 the anticyclone showed high micronekton acoustic densities in the total water column (1461

$398 \pm 531 \mathrm{~m}^{2} \mathrm{nmi}^{-2}$ ), with the acoustic backscatter being distributed almost equally in the surface

399 and deep layers (506 \pm 345 and $559 \pm 298 \mathrm{~m}^{2} \mathrm{nmi}^{-2}$ respectively) and in lower concentrations

400 in the intermediate layer $\left(397 \pm 154 \mathrm{~m}^{2} \mathrm{nmi}^{-2}\right)$. This station can be considered as being

401 anomalous compared to the other anticyclonic stations. However, when this station was

402 removed from the above KW and pairwise analyses, the outcome remained unchanged.

To summarise, the cyclonic stations recorded the greatest micronekton acoustic densities of the total water column and were characterised by negative SLA compared to the other station categories (Fig. 9b). The cyclonic and shelf stations were characterised by the coldest temperature at $100 \mathrm{~m}$, shallower Fmax, the largest integrated chlorophyll $a$ concentrations between 2 and $200 \mathrm{~m}$ and the greatest mean zooplankton biovolumes (Fig. 9c-f). The anticyclone recorded lower micronekton acoustic densities in the total water column compared to the cyclonic ones (Fig. 9a). These stations were characterised by positive SLA, warmer temperature values at 100 m, deeper Fmax, lower integrated chlorophyll $a$ between 2 and $200 \mathrm{~m}$ and higher variability of zooplankton biovolumes compared to cyclonic stations (Fig. 9b-f). The seamount summit stations did not exhibit remarkable micronekton acoustic densities, nor integrated chlorophyll $a$ and mean zooplankton biovolumes among station categories (Fig. 9a, e, f). The station at the dipole interface recorded the lowest micronekton acoustic densities, although values were not significant $(\mathrm{p}<0.05)$ compared to the other

416 station categories, and were characterised by slightly negative SLA (Fig. 9a, b) and the 417 highest mean current speed of $99.1 \mathrm{~m} \mathrm{~s}^{-1}$ compared to all other stations (mean \pm S.D. of 40.6 $\left.418 \pm 19.2 \mathrm{~m} \mathrm{~s}^{-1}\right)$. 
During the La Pérouse cruise, the seamount was under the influence of a weak cyclonic eddy

421 with geostrophic speeds of less than $1 \mathrm{~m} \mathrm{~s}^{-1}$ and satellite surface Absolute Dynamic

422 Topography heights of $\sim 1.1 \mathrm{~m}$ (Fig. 10). ADCP measurements recorded a current velocity of

$423 \sim 10-40 \mathrm{~cm} \mathrm{~s}^{-1}$ at the vicinity of La Pérouse seamount, in the upper $200 \mathrm{~m}$ (Marsac et al.,

424 2020). Surface temperatures ranged between 23 and $24^{\circ} \mathrm{C}$, with a deeper thermocline (152-

$425181 \mathrm{~m}$ ) at La Pérouse (flanks and offshore stations combined) compared to MAD-Ridge

426 cyclonic stations. Maximum chlorophyll $a$ values of $0.18-0.44 \mathrm{mg} \mathrm{m}^{-3}$ at Fmax depth between

$427 \quad 65$ and $140 \mathrm{~m}$ were recorded at all stations.

3.6 Comparison of micronekton acoustic densities at both seamounts

429

430

431

432

433

434

435

436

437

438

439

440

441

RGB composite images showed relatively low but dominant $38 \mathrm{kHz}$ backscatter between

442

443

444

Wilcoxon tests performed for the $38 \mathrm{kHz}$ frequency showed the overall acoustic densities of the depth categories (surface, intermediate and deep) differed significantly between La Pérouse and MAD-Ridge and between day and night $(\mathrm{p}<0.05)$ along the transects mapped in

Fig. 11. The mean acoustic densities for the $38 \mathrm{kHz}$ frequency of the total water column (10$735 \mathrm{~m}$ ) were lower over La Pérouse summit and flanks (Fig. 11a) both during the day (653 \pm $\left.689 \mathrm{~m}^{2} \mathrm{nmi}^{-2}\right)$ and night $\left(903 \pm 600 \mathrm{~m}^{2} \mathrm{nmi}^{-2}\right)$ compared to MAD-Ridge (Day: $1448 \pm 1268$ $\mathrm{m}^{2} \mathrm{nmi}^{-2}$; Night: $2261 \pm 1035 \mathrm{~m}^{2} \mathrm{nmi}^{-2}$ ) summit and flanks (Fig. 11b). During the day and night, the surface layer gathered greater percentage acoustic responses compared to the deep layer both at La Pérouse (Day, Surface: 87.5\%; Deep: 7.2\%; Night, Surface: 94.2\%, Deep: 0.6\%) and MAD-Ridge (Day, Surface: 57.2\%; Deep: 34.6\%; Night, Surface: $74.3 \%$, Deep: $17.0 \%)$. The intermediate layer gathered percentage acoustic densities of 5 to $9 \%$ both during the day and night and at both seamounts.

depths of $\sim 20$ and $60 \mathrm{~m}$ both at La Pérouse (Fig. 12a) and MAD-Ridge seamounts (Fig. 12b) during the day. A stronger response to the $120 \mathrm{kHz}$ frequency compared to the $38 \mathrm{kHz}$ was observed between $\sim 100$ and 180 m depths at La Pérouse and between $\sim 100$ to $125 \mathrm{~m}$ depths 
446 dominant compared to the $70 \mathrm{kHz}$ backscatter between depths of 20 and $180 \mathrm{~m}$ both at La

447 Pérouse and MAD-Ridge (Fig. 12c and 12d). Regions of high acoustic densities (seen as

448 "white patches" on RGB composite images) were observed on La Pérouse and MAD-Ridge summits both during the day and night (Fig. 12a, b, c and d).

450

\section{Discussion}

This study demonstrated the strong influence of mesoscale cyclonic and anticyclonic eddies on the physical and biological properties at MAD-Ridge seamount. The doming of isotherms and shallowing of the Fmax depth was observed within the cyclonic eddy during the MADRidge cruise. Such processes are associated with eddy-induced pumping and upwelling of cool, nutrient-rich waters, triggering an increase in primary production in the photic layer (McGillicuddy and Robinson, 1997; McGillicuddy et al., 1998; Klein and Lapeyre, 2009; Huggett, 2014; Singh et al., 2015). Phytoplankton within mesoscale cyclonic eddies can also grow in response to advection and subsequent retention of surrounding nutrient-rich waters within eddies (José et al., 2014; Lamont et al., 2014). The anticyclonic eddy in this study was characterised by a deeper thermocline and Fmax, with a decrease in productivity in the photic layer than in the cyclonic eddy.

The Madagascar shelf also had a significant effect on the physical and biological processes during the MAD-Ridge cruise. The thermocline and Fmax depth were shallower on the shelf than at the other stations within the anticyclonic eddy. Previous studies have shown that the coastal regions south of Madagascar are more productive than surrounding waters (Raj et al., 2010; Pripp et al., 2014; Ramanantsoa et al., 2018; Annasawmy et al., 2019) owing to coastal upwelling events driven by interactions between the East Madagascar Current and the 

continental shelf and by upwelling favourable winds (Ramanantsoa et al., 2018). This

471 productivity can be entrained by mesoscale features that spin off the East Madagascar

472 Current, farther south, potentially towards MAD-Ridge (Noyon et al., 2018; Ockhuis et al., 2017).

474 La Pérouse seamount, on the other hand, is located on the edge of the ISSG and was under 475 the influence of a weak mesoscale eddy field during the cruise there, reflecting average 476 conditions observed throughout the year in this region, as shown by Pous et al. (2014) using 477 the OSCAR product (https://podaac.jpl.nasa.gov/dataset/OSCAR_L4_OC_third-deg). Apart 478 from disturbances caused by the seamount to circulation, phytoplankton and zooplankton at a 479 small scale along the flanks (Marsac et al., 2020), the average conditions in the La Pérouse 480 area with relatively deep thermocline and Fmax depth, were typical of the oligotrophic ISSG province. Overall, during the time of the cruises, sea surface chlorophyll concentrations were twice as low within the region of the La Pérouse seamount as at the MAD-Ridge seamount (Annasawmy et al., 2019).

4.2 Diel vertical migration of micronekton

Micronekton is a diverse group of organisms capable of demonstrating various swimming behaviours (active swimming or passive drifting) and vertical migration strategies (diel migrants, semi-migrants or non-migrants) (Brodeur and Yamamura 2005). In this study, the different DVM patterns of micronekton were observed. Vertically migrating organisms ascended to the surface (above $200 \mathrm{~m}$ ) at sunset and descended below $400 \mathrm{~m}$ at sunrise in the vicinity of both MAD-Ridge and La Pérouse, whereas only a small proportion of non-migrant or semi-migrant micronekton remained in the deep layer by day at both seamounts. On average, a difference of $595 \mathrm{~m}^{2} \mathrm{nmi}^{-2}$ to $1719 \mathrm{~m}^{2} \mathrm{nmi}^{-2}$ was recorded between day and night periods at MAD-Ridge (West-East and South-North transects) and a difference of $790 \mathrm{~m}^{2}$ $\mathrm{nmi}^{-2}$ between day and night at La Pérouse. These differences between alternate day and 
495

496

497

498

499

500

501

502

503

504

505

506

507

508

509

510

511

512

513

514

515

516

517

518

519

night periods are likely caused either by the vertical migration of micronekton towards the surface at night for feeding purposes, sometimes from layers deeper than $735 \mathrm{~m}$ (i.e. beyond the range set for the $38 \mathrm{kHz}$ transducer in this study), and/or the lateral advection of organisms.

Micronekton acoustic densities were greater in the surface layer than in the deep layer during the day at cyclonic eddy stations. This particular finding contradicts the general paradigm that micronekton are located in deeper layers by day (eg. Baliño and Aksnes, 1993; Andersen et al., 1998; Bertrand et al., 1999; Lebourges-Dhaussy et al., 2000; Benoit-Bird and Au, 2004; Domokos et al., 2010; Godø et al., 2009, 2012; Drazen et al., 2011; Béhagle et al., 2014; Menkes et al., 2015; Béhagle et al., 2017; Bianchi and Mislan, 2016; Annasawmy et al., 2018). Micronekton do not only undertake direct swimming in vertical and horizontal planes, but may also drift passively. Previous studies have reported passive drifting of the mesopelagic myctophid Benthosema glaciale with swimming speeds of $0-0.02 \mathrm{~m} \mathrm{~s}^{-1}$ along weak tidal currents and short bouts of active swimming in a vertical direction with swimming speeds of $0.05 \mathrm{~m} \mathrm{~s}^{-1}$, possibly during feeding (Torgersen and Kaartvedt, 2001; Kaartvedt et al., 2009). This species has also been reported to undertake reverse DVM, ascending to approximately $200 \mathrm{~m}$ by day to forage on midwater plankton (Kaartvedt et al., 2009). The reverse DVM pattern is not common, with only some species of zooplankton (Ohman et al., 1983; Lampert, 1989) and mesopelagic fish having been reported to ascend to the surface layer during the day to optimise feeding opportunities (Lebourges-Dhaussy et al., 2000; Kaartvedt et al., 2009).

Some micronekton taxa may also preferentially stay in the surface layer during the day to reduce competition during feeding. The micronekton species Myctophum asperum, Myctophum nitidulum, Symbolophorus evermanni, and Chromis brevirostis showed delayed vertical migration at night in the Kuroshio region of the western North Pacific, with specific 

peak feeding hours and specialisation on different food organisms in order to reduce

521 competition (Watanabe et al., 2002). Daylight surface observations are rare but were made

522 for the mesopelagic fish Benthosema pterotum in the Gulf of Oman (Gjøsæter, 1978, 1984),

523 the myctophid Benthosema pterota off the coast of Central America (Alverson, 1961) and the

524 myctophid Vinciguerria nimbaria in the eastern Tropical Atlantic (Marchal and Lebourges-

525 Dhaussy, 1996; Lebourges-Dhaussy et al., 2000). The reasons for the daylight surface

526 occurrence of $V$. nimbaria has been linked to the presence of potential preys such as 527 zooplankton at the Fmax depth (Lebourges-Dhaussy et al., 2000). Previous studies have also 528 found the deep-dwelling cod Micromesistius poutassou wich usually resides at a depth of $300-500 \mathrm{~m}$, migrating to the surface of anticyclonic eddies probably to enhance feeding 530 opportunities (Godø et al., 2012). Micronekton organisms within the cyclonic eddy during 531 MAD-Ridge might have adopted a combination of these strategies and this possibility is discussed in more detail below.

4.3 Influence of mesoscale features on micronekton vertical and horizontal distribution

As shown earlier, the vertical and horizontal distributions of micronekton at MAD-Ridge were significantly influenced by mesoscale processes linked to the presence of cyclonic and anticyclonic eddies. The daytime $\mathrm{s}_{\mathrm{A}}$ values within the eddy dipole interface were the lowest relative to the other hydrographic station categories used in this analysis. Harris et al. (2020) also recorded lower larval fish densities at the eddy dipole interface than at cyclonic and anticyclonic circulation stations. This can be attributed to the strong currents measured at this

540 location that have led to the dispersion of micronekton communities. Alternatively, micronekton may have migrated below the depth range scanned by the $38 \mathrm{kHz}$ transducer at that station due to a combination of strong currents and daytime light intensities.

543 Overall, acoustic densities of the total water column recorded within the cyclonic eddy were approximately twice as great as those recorded within the anticyclonic circulation during both 
day and night. The integrated chlorophyll $a$ and zooplankton biovolume maxima found in the cyclonic eddy, matched the micronekton maxima, during day and night. Micronekton biomass is reported to be dependent on the availability of planktonic prey (Menkes et al., 2015), and hence on the oceanographic drivers of plankton production, as observed in this study. In the anticyclonic eddy, the downwelling mechanism of nutrient-depleted surface waters may have led to a reduction of chlorophyll $a$ concentrations in the euphotic zone, and a subsequent reduction in mesozooplankton abundance and micronekton acoustic densities during both day and night. Previous studies conducted in the Mozambique Channel have also reported lesser micronekton acoustic densities in anticyclonic relative to cyclonic eddies (Béhagle et al., 2014). However, the same authors pointed out some variability in eddyinduced biological responses, with one case of higher micronekton density in an anticyclonic eddy that was attributed to larger and more mobile organisms that are less influenced by mesoscale features than smaller organisms.

The RGB composite images have revealed the presence of a strong and dominant $38 \mathrm{kHz}$ backscatter in the surface layer during the day across the cyclonic eddy (Fig 3c). Previous studies have demonstrated that epi- and mesopelagic fish with small gas-filled swimbladders and gelatinous plankton with gas inclusions dominate the $38 \mathrm{kHz}$ frequency (Porteiro and Sutton, 2007; Kloser et al., 2002, 2009; Davison et al., 2015; Cascão et al., 2017; Proud et al., 2018; Annasawmy et al., 2019). The occurrence of these organisms at the surface (10-200 m) by day may be considered a response to the cyclonic eddy exhibiting relatively high integrated chlorophyll $a$ concentrations and zooplankton biovolumes. The question arises, though, whether these micronekton species showed reverse migration strategies and actively remained in the shallow layer by day or whether they were passively entrained with the current within the cyclonic circulation. This shallow scattering layer may also have consisted of gelatinous organisms, which as other zooplankton, responded to the localised cyclonic productivity. The mesoscale cyclonic eddy may also have provided physical mechanisms that 
572 micronekton and their prey. The micronekton organisms, likely epi- and mesopelagic fish,

573 would then preferentially stay in the surface layer by day to increase their feeding 574 opportunities.

\subsection{Influence of seamounts on micronekton vertical and horizontal distributions}

576

577

578

Dense aggregations of scatterers were observed over deep topographic features labelled X and $\mathrm{Y}$ peaking at $430 \mathrm{~m}$ and $460 \mathrm{~m}$, during night-time and sunrise, respectively (Figure 3b). These dense aggregations may have been migrating during the time of the cruise, upwards over feature $\mathrm{X}$ at night or downwards at feature $\mathrm{Y}$ at sunrise. Alternatively, they may be nonmigrating organisms that remained preferentially associated with these topographic features during day and night. Studies have suggested that the bottom-trapping mechanism as well as the horizontal flux of non-migrating zooplankton maintain the densities of zooplanktivorous fish at seamounts of intermediate depth (Genin and Dower, 2007). A range of other factors such as the quiescent shelters offered by these topographies and the absence of shallow diving predators (Porteiro and Sutton, 2007) may also account for the presence of these dense aggregations at the features labelled $\mathrm{X}$ and $\mathrm{Y}$.

Micronekton acoustic densities over the summit and flanks of MAD-Ridge were lower than the acoustic densities recorded within the cyclonic eddy and over the Madagascar shelf. However, the acoustic densities surrounding MAD-Ridge's summit and flanks were greater than those recorded in the vicinity of the summit and flanks of La Pérouse. Although there were clear mechanisms leading to enhanced productivity within the cyclonic eddy and over the Madagascar shelf, the local physical and biological dynamics over La Pérouse and MADRidge seamounts were less straightforward. No clear enhancement in micronekton acoustic densities was observed over MAD-Ridge compared with the surrounding vicinity (within 14 nautical miles of the summit) at the time of the cruises (Annasawmy et al., 2019). 
In the literature, Taylor columns that form over seamounts are often considered as physical

597 processes that are capable of enhancing productivity and isolating the seamount waters from

598

599

600

601

602

603

604

605

606

607

608

609

610

611

612 the large-scale environment (Genin and Boehlert, 1985; Dower et al., 1992; Genin, 2004). The $\alpha$, Ro and Bl values were above the threshold set in literature (Chapman and Haidvogel, 1992; White et al., 2007) at both La Pérouse and MAD-Ridge during the cruises. The mesoscale eddy activity in the MAD-Ridge area may have dominated any potential seamount effect. The summit of MAD-Ridge during most of the cruise was under the influence of the anticyclonic eddy with current speeds exceeding $0.5 \mathrm{~m} \mathrm{~s}^{-1}$, thus making the formation of a Taylor column very unlikely. The MAD-Ridge's seamount shape may also not be favourable to the formation of such features because the threshold set for $\alpha$ values in theoretical calculations was exceeded. Additionally, because of the presence of the anticyclonic eddy feature over MAD-Ridge's summit, there was a downward deflection of isotherms between the surface and $\sim 200 \mathrm{~m}$, instead of an uplifting as seen across other studies (Genin and Boehlert 1985; Boehlert and Genin, 1987; Dower and Mackas, 1996). MAD-Ridge is located in an "eddy corridor" to the south of Madagascar. Previous studies have found evidence of a westward drift of eddies at an estimated speed of $7.3 \pm 1.7 \mathrm{~cm} \mathrm{~s}^{-1}$ in the vicinity of the pinnacle, along $27^{\circ} \mathrm{S}$ and $45^{\circ} \mathrm{E}$ (Pollard and Read., 2017). Phytoplankton entrapment during several weeks would be needed to allow growth of zooplankton and to attract micronekton species (Genin and Boehlert 1985; Boehlert and Genin, 1987; Dower et al., 1992). In such a dynamic system, strong currents may continuously sweep away phytoplankton cells from the summit. Phytoplankton retention mechanisms may not be sufficiently long to have a significant impact on higher trophic levels such as zooplankton and micronekton, potentially explaining the lower micronekton acoustic densities recorded directly above MAD-Ridge's summit during the cruise relative to the cyclonic eddy and shelf stations.

La Pérouse's pinnacle is believed to cause disruptions in the current velocities because flank stations (within $3 \mathrm{~km}$ of the summit) exhibited a larger diversity of current velocities and 

seamount, the formation of a Taylor column was also very unlikely to have occurred because current speeds of $0.3 \mathrm{~m} \mathrm{~s}^{-1}$ and greater were recorded. The complex crescent shape of the seamount may not be favourable for the development of a steady anticyclonic circulation.

The La Pérouse wider region is under the influence of the anticyclonic circulation pattern of 627 the ISSG province characterised by a deep thermocline, a halocline and a DCM at 100-150 $\mathrm{m}$, with chlorophyll $a$ concentrations $<0.3 \mathrm{mg} \mathrm{m}^{-3}$ between the surface and $200 \mathrm{~m}$ as observed in our study and in Jena et al. (2012, 2013). Overall mean acoustic densities of micronekton at the La Pérouse seamount were thus typical of those of the ISSG province both during day and night (Annasawmy et al., 2018).

Common to both La Pérouse and MAD-Ridge seamounts is the presence of dense aggregations of scatterers (seen as "white patches" on RGB composite images, Fig. 8 and 12a-d) directly above the summits during day and night. A combination of trawls and acoustic data revealed these dense aggregations to consist of the myctophids Diaphus suborbitatis (both La Pérouse and MAD-Ridge), Benthosema fibulatum, Hygophum hygomii and the benthopelagic fish Cookeolus japonicus on MAD-Ridge's summit and flanks (Annasawmy et al., 2019). Populations of D. suborbitalis have also been reported to be located between 500 and $600 \mathrm{~m}$ during the day along the flanks of the Equator seamount in the Indian Ocean, and to ascend to the surface of the seamount at dusk to feed on copepods (Gorelova and Prut'ko, 1985; Parin and Prut'ko, 1985; Porteiro and Sutton, 2007), while $B$. fibulatum has been found associated with the Hawaiian Cross seamount in the Pacific (De Forest and Drazen, 2009). Dense aggregations of scatterers were also observed above a ridge off the coast of Baja California and was thought to consist of the fish Sebastodes, anchovy and juvenile hake that prey on migrating zooplankton (Isaacs and Schwartzlose, 1965). Similar aggregations of scatterers were observed on the South East Hancock seamount in the central North Pacific, consisting of resident populations of the fish Maurolicus muelleri and 
649 showed these organisms to be concentrated on the seamount flanks at $400 \mathrm{~m}$, before rising to

650 the surface at dusk and streaming vertically downwards at dawn, with some scatterers

651 remaining above the flanks at $170 \mathrm{~m}$ even during daylight. The association of these fish with

652 seamounts may confer some selective advantages such as enhanced feeding opportunities,

653 increased habitat diversity (Wilson and Boehlert, 2004; Porteiro and Sutton, 2007), shelter

654 areas for spawning, or decreased energy loss by using the seamount as a shelter during non-

655 feeding intervals (Cascão et al., 2017).

656 The maintenance of a population at a seamount also depends on local recruitment or

657 advection of eggs and larvae from the shelf or neighbouring islands and seamounts (Boehlert

658 et al., 1994; Diekmann et al., 2006). According to Harris et al. (2020), higher larval densities

659 mostly of the families Myctophidae, Bregmacerotidae, Gonostomatidae and Molidae were

660 recorded at MAD-Ridge's summit. According to those authors, this observation points to

661 some local spawning processes at the pinnacle. The MAD-Ridge seamount is close to shallow

662 and deep topographic structures and to the Madagascar shelf, features from which larvae

663 might have been advected (Crochelet et al., 2020). The presence of a greater proportion of

664 neritic species over the summit of MAD-Ridge seamount relative to La Pérouse seems to

665 favour this hypothesis (Harris et al., 2020). The mesoscale activity on the Madagascar shelf

666 and at MAD-Ridge may allow the periodic replenishment of advected larvae over the

667 pinnacle (Harris et al., 2020; Crochelet et al., 2020), corresponding with enhanced

668 micronekton acoustic densities compared to La Pérouse.

669

\section{$670 \quad$ 5. Concluding Remarks}

671 This study has suggested a link between the physical processes leading to enhanced 672 productivity and the biological response of micronekton. Two main processes were identified 
673

674

675

676

677

678

679

680

681

682

683

684

685

686

687

688

689

690

691

692

693

694

to have a positive effect on the observed productivity: 1) the influence of the cyclonic eddy through the enrichment of surface waters, 2) the advection of shelf waters with high chlorophyll $a$ concentrations. La Pérouse and MAD-Ridge seamounts did not show any enhanced biomass of micronekton, as reported to be the case for other seamounts. However, despite the differing productivity levels at both seamounts, dense aggregations of scatterers were observed on the summits during day and night. This study has therefore suggested that seamount-associated species were the only seamount effect detected and that in a highly dynamic environment like south of Madagascar, mesoscale features have a stronger influence than seamounts on micronekton acoustic densities.

\section{Acknowledgements}

We acknowledge the work carried out by the non-scientific and scientific staff on board the RV Antea in taking part in the data acquisition and data processing. The study was mainly supported by the Flotte Océanographique Française (French Oceanographic Fleet) and IRD in relation to the logistics of the RV Antea. Additional funding was also received from Région Reunion (Réunion Regional Council) for the La Pérouse cruise, and from the Fonds Français pour l'Environnement Mondial (FFEM) as part of the FFEM-SWIO project on Areas Beyond National Jurisdiction (ABNJ) of the South West Indian Ocean for the MAD-Ridge cruise. The first author was the beneficiary of a doctoral bursary granted by the Institut de Recherche pour le Développement (IRD, France) and the ICEMASA French-South African International Laboratory. 
Alverson, F.G., 1961. Daylight Surface Occurrence of Myctophid Fishes Off the Coast of Central America. Pac Sci. 15(3): 483. http://hdl.handle.net/10125/9088

Andersen, V., François, F., Sardou, J., Picheral, M., Scotto, M., Nival, P., 1998. Vertical distributions of macroplankton and micronekton in the Ligurian and Tyrrhenian Seas (northwestern Mediterranean). Oceanologica Acta. 21(5): 655-676.

Annasawmy, P., Ternon, J.F., Marsac, F., Cherel, Y., Béhagle, N., Roudaut, G., LebourgesDhaussy, A., Demarcq, H., Moloney, C.L., Jaquemet, S., Ménard, F., 2018. Micronekton diel migration, community composition and trophic position within two biogeochemical provinces of the South West Indian Ocean: Insight from acoustics and stable isotopes. Deep-Sea Res. I. 138: 85-97. https://doi.org/10.1016/j.dsr.2018.07.002

Annasawmy, P., Ternon, J-F., Cotel, P., Demarcq, H., Cherel, Y, Romanov, E., Roudaut, G., Lebourges-Dhaussy, A., Ménard, F., Marsac, F. 2019. Micronekton distribution and assemblages at two shallow seamounts in the south-western Indian Ocean: Insights from acoustics and mesopelagic trawl data. Prog. Oceanogr. https://doi.org/10.1016/j.pocean.2019.102161

Bakun, A., 2006. Fronts and eddies as key structures in the habitat of marine fish larvae: opportunity, adaptive response and competitive advantage. Sci. Mar. 70, 105-122. https://doi.org/10.3989/scimar.2006.70s2105

Baliño, B.M, Aksnes, D.L., 1993. Winter distribution and migration of the sound scattering layers, zooplankton and micronekton in Masfjorden, western Norway. Mar. Ecol. Prog. Ser. 102: 35-50. https://www.int-res.com/articles/meps/102/m102p035.pdf

Béhagle, N., du Buisson, L., Josse, E., Lebourges-Dhaussy, A., Roudaut, G., Ménard, F., 2014. Mesoscale features and micronekton in the Mozambique Channel: An acoustic approach. Deep-Sea Res. II. 100: 164-173. http://dx.doi.org/10.1016/j.dsr2.2013.10.024

Béhagle, N., Cotté, C., Lebourges-Dhaussy, A., Roudaut, G., Duhamel, G., Brehmer, P., Josse, E., Cherel, Y., 2017. Acoustic distribution of discriminated micronektonic organisms from a bi-frequency processing: The case study of eastern Kerguelen oceanic waters. Progress in Oceanography, 156: 276-289. https://doi.org/10.1016/j.pocean.2017.06.004

Benitez-Nelson, C.R., McGillicuddy, D. J., 2008. Mesoscale Physical-BiologicalBiogeochemical Linkages in the Open Ocean: An Introduction to the results of the EFlux and EDDIES Programs. Deep-Sea Res. II. 55(10-13): 1133-38. https://doi.org/10.1016/j.dsr2.2008.03.001

Benoit-Bird, K.J., Au, W.W.L, 2004. Diel migration dynamics of an island-associated soundscattering layer. Deep-Sea Res. I. 51: 707-719. doi:10.1016/j.dsr.2004.01.004

Bertrand, A., Le Borgne, R., Josse, E., 1999. Acoustic characterisation of micronekton distribution in French Polynesia. Mar. Ecol. Prog. Ser. 191: 127-140. doi:10.3354/meps 191127

Bertrand, A., Bard, F.X. Josse, E., 2002. Tuna food habits related to the micronekton distribution in French Polynesia. Mar Biol. 140: 1023-1037. doi:10.1007/s00227-0010776-3

Bianchi, D., Stock, C., Galbraith, E.D., Sarmiento, J.L., 2013. Diel vertical migration: Ecological controls and impacts on the biological pump in a one-dimensional ocean model. Global Biogeochem. Cycles. 27: 478-491. doi:10.1002/gbc.20031.

Bianchi, D., Mislan, K.A.S., 2016. Global patterns of diel vertical migration times and velocities from acoustic data. Limnol. Oceanogr. 61: 353-364. doi: 10.1002/lno.10219 
Boehlert, G.W., Genin, A., 1987. A review of the effects of seamounts on biological processes. B. Keating, P. Fryer, R. Batiza (Eds.), Seamounts, islands and atolls, American Geophysical Union, Washington, D.C (1987), pp. 319-334

Boehlert, G.W., 1988. Current-Topography Interactions at Mid-Ocean Seamounts and the Impact on Pelagic Ecosystems. GeoJournal, 16.1: 45-52.

Boehlert, G.W., Wilson, C.D., Mizuno, K., 1994. Populations of the Sternoptychid Fish Maurolicus muelleri on Seamounts in the Central North Pacific. Pac. Sci. 48(1): 5769.

Brierley, A.S., 2014. Diel vertical migration. Current Biology. 24(22): R1074-R1076. https://doi.org/10.1016/j.cub.2014.08.054

Brodeur, R.D., Seki, M.P., Pakhomov, E.A., Suntsov, A.V., 2005. Micronekton-What are they and why are they important? PICES Press 14: 7-11.

Brodeur, R.D., Yamamura, O., 2005. PICES Scientific Report No. 30 Micronekton of the North Pacific. PICES Scientific Report, Sidney, B.C., Canada, pp. 1-115.

Cascão, I., Domokos, R., Lammers, M.O., Marques, V., Domínguez, R., Santos, R.S., Silva, M.A., 2017. Persistent Enhancement of Micronekton Backscatter at the Summits of Seamounts in the Azores. Front. Mar. Sci. 4: 25. https://doi.org/10.3389/fmars.2017.00025

Catul, V., Gauns, M., Karuppasamy, P.K., 2011. A review of mesopelagic fishes belonging to family Mcytophidae. Rev. Fish Biol. Fisheries. 21: 339-354. doi: 10.1007/s11160010-9176-4

Chapman, D.C., Haidvogel, D.B., 1992. Formation of Taylor Caps over a tall isolated seamount in a stratified ocean. Geophysical and Astrophysical Fluid Dynamics. 64: $31-65$.

Chelton, D.B., Schlax, M.G., Samelson, R.M., 2011. Global observations of nonlinear mesoscale eddies. Prog. Oceanogr. 91: 167-216. https://doi.org/10.1016/j.pocean.2011.01.002

Cherel, Y., Fontaine, C., Richard, P., Labat, J-P., 2010. Isotopic niches and trophic levels of myctophid fishes and their predators in the Southern Ocean. Limnol. Oceanogr. 55(1): 324-332. https://doi.org/10.4319/lo.2010.55.1.0324

Cherel, Y., Romanov, E.V., Annasawmy, P., Thibault, D., Ménard, F., 2020. Micronektonic fish species over three seamounts in the southwestern Indian Ocean and myctophid infestation by the copepod Cardiodectes bellotti. Deep-Sea Res. II.

Crochelet, E., Barrier, N., Andrello, M., Marsac, F., Spadone, A., Lett, C., 2020. Connectivity between seamounts and coastal ecosystems in the South West Indian Ocean. Deep Sea Res. Part II.

Danckwerts, D.K., McQuaid, C.D., McGregor, G.K., Dwight, R., Le Corre, M., Jaquemet, S., 2014. Biomass consumption by breeding seabirds in the western Indian Ocean: indirect interactions with fisheries and implications for management. ICES J. Mar. Sci. 71(9): 2589-2598. doi:10.1093/icesjms/fsu093

Davison, P.C., Koslow, J.A., Kloser, R.J. 2015. Acoustic biomass estimation of mesopelagic fish: backscattering from individuals, populations, and communities. ICES J. Mar. Sci. 72(5): 1413-1424. doi:10.1093/icesjms/fsv023

De Forest, L., Drazen, J., 2009. The influence of a Hawaiian seamount on mesopelagic micronekton. Deep-Sea Res I. 56: 232-250. doi:10.1016/j.dsr.2008.09.007

De Robertis, A., Higginbottom, I., 2007. A post-processing technique to estimate the signal-to-noise ratio and remove echosounder background noise. ICES J. Mar. Sci. 64: 1282-1291. https://doi.org/10.1093/icesjms/fsm112

Diekmann, R., Nellen, W., Piatkowski, U., 2006. A multivariate analysis of larval fish and paralarval cephalopod assemblages at Great Meteor Seamount. Deep-Sea Res. I. 53: 1635-1657. doi:10.1016/j.dsr.2006.08.008 
Domokos, R., Pakhomov, E.A., Suntsov, A.V., Seki, M.P., Polovina, J.J., 2010. Acoustic Characterization of the Mesopelagic Community off the Leeward Coast of Oahu Island, Hawaii. In: Report of the Advisory Panel on Micronekton Sampling Intercalibration Experiment Edition: 38Publisher: PICES Scientific Report [Eds]: Pakhomov, E.A., Yamamura, O.

Dower, J., Freeland, H., Juniper, K., 1992. A strong biological response to oceanic flow past Cobb Seamount. Deep-Sea Res. 39(7/8): 1139-1145. https://doi.org/10.1016/01980149(92)90061-W

Dower, J.F., Mackas, D.L., 1996. "Seamount effects" in the zooplankton community near Cobb Seamount. Deep-Sea Res. I. 43(6): 837-858. https://doi.org/10.1016/09670637(96)00040-4

Drazen, J.C., De Forest, L.G., Domokos, R., 2011. Micronekton abundance and biomass in Hawaiian waters as influenced by seamounts, eddies and the moon. Deep-Sea Res. I. 58: 557-566. doi:10.1016/j.dsr.2011.03.002

Dufois, F., Hardman-Mountford, N.J., Greenwood, J., Richardson, A.J., Feng, M., Herbette, S., Matear, R., 2014. Impact of eddies on surface chlorophyll in the South Indian Ocean. J. Geophys. Res. Oceans. 119: 8061-8077. https://doi.org/10.1002/2014JC010164

Foote, K.G., Knudsen, H.P., Vestnes, G., MacLennan, D.N., Simmonds, E.J., 1987. Calibration of acoustic instruments for fish density estimation: a practical guide. ICES Coop. Res. Rep. 144: 1-69.

Genin, A., Boehlert, G.W., 1985. Dynamics of temperature and chlorophyll structures above a seamount: An oceanic experiment. J. Mar. Res. 43: 907-924.

Genin, A., 2004. Bio-physical coupling in the formation of zooplankton and fish aggregations over adrupt topographies. J. Mar. Sci. 50: 3-20. doi:10.1016/j.jmarsys.2003.10.008

Genin, A., Dower, J.F., 2007. Seamount Plankton Dynamics. In: Pitcher, T.J., Morato, T., Hart, P.J.B., Clark, M.R., Haggan, N., Santos, R.S. (Eds), Seamounts: Ecology,

Fisheries \& Conservation. Blackwell Publishing Ltd, Oxford, UK, pp. 85-100.

Gjøsæter, J., 1978. Aspects of the distribution and ecology of the Myctophidae from the Western and Northern Arabian Sea. Development Report Indian Ocean Programme, 43: 62-108.

Gjøsaeter, J., 1984. Mesopelagic fish, a large potential resource in the Arabian Sea. Deep-Sea Res. Part A. 31:1019-1035.

Godø, O.R., Patel, R., Pedersen, G., 2009. Diel migration and swimbladder resonance of small fish: some implications for analyses of multifrequency echo data. ICES J. Mar. Sci. 66: 1143-1148. https://doi.org/10.1093/icesjms/fsp098

Godø, O.R., Samuelsen, A., Macaulay, G.J., Patel, R., Hjøllo, S.S., Horne, J., Kaartvedt, S., Johannessen, J.A., 2012. Mesoscale Eddies Are Oases for Higher Trophic Marine Life. PLoS ONE. 7(1): e30161. https://doi.org/10.1371/journal.pone.0030161

Gorelova T.A., Prutko, V.G., 1985. On feeding of Diaphus suborbitalis (Myctophidae, Pisces) in the equatorial Indian Ocean. Okeanologya. 25: 677-684 (in Russian).

Gorsky, G., Ohman, M.D., Picheral, M., Gasparini, S., Stemmann, L., Romagnan, J-B., Gawood, A., Pesant, S., García-Lomas, C., Prejger, F., 2010. Digital zooplankton image analysis using the ZooScan integrated system. J. Plankton Res. 32(3): 285-303. doi:10.1093/plankt/fbp124

Guinet, C., Cherel, Y., Ridoux, V., Jouventin, P., 1996. Consumption of marine resources by seabirds and seals in Crozet and Kerguelen waters: changes in relation to consumer biomass 1962-85. Antarctic Science. 8(1): 23-30.

Halo, I., Backeberg, B., Penven, P., Ansorge, I., Reason, C., Ullgren, J.E., 2014. Eddy properties in the Mozambique Channel: A comparison between observations and two 
numerical ocean circulation models. Deep-Sea Res. II. 100: 38-53. http://dx.doi.org/10.1016/j.dsr2.2013.10.015

Harris, S.A., Noyon, M., Roberts, M., Marsac, F., 2020. Ichthyoplankton assemblages at three shallow seamounts in the South West Indian Ocean: La Pérouse, MAD-Ridge and Walters Shoal. Deep Sea Res. Part II.

Heywood, K.J., 1996. Diel vertical migration of zooplankton in the Northeast Atlantic. Journal of Plankton Research. 18(2): 163-184.

Hidaka, K., Kawaguchi, K., Murakami, M., Takahashi, M., 2001. Downward transport of organic carbon by diel migratory micronekton in the western equatorial Pacific: its quantitative and qualitative importance. Deep-Sea Res. I. 48: 1923-1939.

Huggett, J.A., 2014. Mesoscale distribution and community composition of zooplankton in the Mozambique Channel. Deep-Sea Res. II. 100: 119-135. http://dx.doi.org/10.1016/j.dsr2.2013.10.021

Isaacs, J.D., Schwartzlose, R.A., 1965. Migrant Sound Scatterers: Interaction with the Sea Floor. Science. 150, 1810-1813. https://doi.org/10.1126/science.150.3705.1810

Isern-Fontanet, J., Font, J., García-Ladona, E., Emelianov, M., Millot, C., Taupier-Letage, I., 2004. Spatial structure of anticyclonic eddies in the Algerian basin (Mediterranean Sea) analyzed using the Okubo-Weiss parameter. Deep-Sea Res. II. 51: 3009-3028. doi:10.1016/j.dsr2.2004.09.013

Jaquemet, S., Ternon, J.F., Kaehler, S., Thiebot, J.B., Dyer, B., Bemanaja, E., Marteau, C., Le Corre, M., 2014. Contrasted structuring effects of mesoscale features on the seabird community in the Mozambique Channel. Deep-Sea Res. II. 100: 200-211. http://dx.doi.org/10.1016/j.dsr2.2013.10.027

Jena, B., Swain, D., Avinash, K., 2012. Investigation of the biophysical processes over the oligotrophic waters of South Indian Ocean subtropical gyre, triggered by cyclone Edzani. International Journal of Applied Earth Observation and Geoinformation 18: 49-56. doi:10.1016/j.jag.2012.01.006

Jena, B., Sahu, S., Avinash, K., Swain, D., 2013. Observation of oligotrophic gyre variability in the south Indian Ocean: Environmental forcing and biological response. Deep-Sea Res. I. 80: 1-10. http://dx.doi.org/10.1016/j.dsr.2013.06.002

Johnston, D. W., McDonald, M., Polovina, J., Domokos, R., Wiggins, S., Hildebrand, J., 2008. Temporal patterns in the acoustic signals of beaked whales at Cross Seamount. Biol. Lett. 4: 208-211. https://doi.org/10.1098/rsbl.2007.0614

José, Y.S., Aumont, O., Machu, E., Penven, P., Moloney, C.L., Maury, O., 2014. Influence of mesoscale eddies biological production in the Mozambique Channel: Several contrasted examples from a coupled ocean-biogeochemistry model. Deep-Sea Res. II. 100: 79-93. http://dx.doi.org/10.1016/j.dsr2.2013.10.018

Judkins, D.C., Haedrich, R.L., 2018. The deep scattering layer micronektonic fish faunas of the Atlantic mesopelagic ecoregions with comparison of the corresponding decapod shrimp faunas. Deep-Sea Res. I. 136: 1-30. https://doi.org/10.1016/j.dsr.2018.04.008

Kaartvedt, S., Røstad, A., Klevjer, T., Staby, A., 2009. Use of bottom-mounted echo sounders in exploring behavior of mesopelagic fishes. Mar. Ecol. Prog. Ser. 395, 109-118. https://doi.org/10.3354/meps08174

Klein, P., Lapeyre, G., 2009. The Oceanic Vertical Pump Induced by Mesoscale and Submesoscale Turbulence. Annu. Rev. Mar. Sci. 1, 351-375. https://doi.org/10.1146/annurev.marine.010908.163704

Kloser, R.J., Ryan, T., Sakov, P., Williams, A., Koslow, J.A., 2002. Species identification in deep water using multiple acoustic frequencies. Canadian Journal of Fisheries and Aquatic Sciences. 59:1065-1077. 
Kloser, R.J., Ryan, T.E., Young, J.W., Lewis, M.E., 2009. Acoustic observations of micronekton fish on the scale of an ocean basin: potential and challenges. ICES J. Mar. Sci. 66(6): 998-1006, https://doi.org/10.1093/icesjms/fsp077

Kloser, R.J., Ryan, T.E., Keith, G., Gershwin, L., 2016. Deep-scattering layer, gas-bladder density, and size estimates using a two-frequency acoustic and optical probe. ICES J Mar Sci. 73(8): 2037-2048. DOI:10.1093/icesjms/fsv257

Lamont, T., Barlow, R.G., Morris, T., van den Berg, M.A., 2014. Characterisation of mesoscale features and phytoplankton variability in the Mozambique Channel. Deep Sea Res. Part II Top. Stud. Oceanogr. 100: 94-105. https://doi.org/10.1016/j.dsr2.2013.10.019

Lampert, W., 1989. The Adaptive Significance of Diel Vertical Migration of Zooplankton. Functional Ecology, 3(1): 21-27. doi:10.2307/2389671

Lebourges-Dhaussy, A., Marchal, E., Menkès, C., Champalbert, G., Biessy, B., 2000. Vinciguerria nimbaria (micronekton), environmetn and tuna: their relationships in the Eastern Tropical Atlantic. Oceanologica Acta. 23(4): 515-528.

Lehodey, P., Murtugudde, R., Senina, I., 2010. Bridging the gap from ocean models to population dynamics of large marine predators: A model of mid-trophic functional groups. Prog. Oceanogr. 84: 69-84. DOI:10.1016/j.pocean.2009.09.008

Lévy, M., Klein, P., Treguier, A-M., 2001. Impact of sub-mesoscale physics on production and subduction of phytoplankton in an oligotrophic regime. J. Mar. Res. 59: 535-565.

Lévy, M., Franks, P.J.S., Smith, K.F. 2018. The role of submesoscale currents in structuring marine ecosystems. Nature Communications. 9(4758). DOI: 10.1038/s41467-01807059-3

Longhurst, A., 2007. The Indian Ocean-Indian South Subtropical Gyre Province (ISSG). In: Academic Press (Ed.), Ecological Geography of the Sea, 2nd ed. Elsevier, USA, pp. 285.

MacLennan, D.V., Fernandes, P.G., Dalen, J. 2002. A consistent approach to definitions and symbols in fisheries acoustics. ICES J. Mar. Sci. 59: 365-369. doi:10.1006/jmsc.2001.1158

Mann, K.H., Lazier, J.R., 2006. Dynamics of marine ecosystems: biological-physical interactions in the oceans. (Third edition), John Wiley and Sons (2006).

Marchal, E., Lebourges-Dhaussy, A., 1996. Acoustic evidence for unusual diel behaviour of a mesopelagic fish (Vinciguerria nimbaria) exploited by tuna. ICES J. Mar. Sci. 53, 443-447. https://doi.org/10.1006/jmsc.1996.0062

Marsac, F., Annasawmy, P., Noyon, M., Demarcq, H., Soria, M., Rabearisoa, N., Bach, P., Cherel, Y., Grelet, J., Romanov, E., 2020. Seamount effect on circulation and distribution of ocean taxa at and near La Pérouse, a shallow seamount in the southwestern Indian Ocean. Deep-Sea Res. Part II.

McGillicuddy, D.J., Robinson, A.R., 1997. Eddy-induced nutrient supply and new production in Sargasso Sea. Deep-Sea Res. I. 44(8): 1427-1450.

McGillicuddy, D.J., Robinson, A.R., Siegel, D.A., Jannasch, H.W., Johnson, R., Dickey, T.D., McNell, J., Michaels, A.F., Knap, A.H., 1998. Influence of mesoscale eddies on new production in the Sargasso Sea. Nature. 394: 263-266.

McGillicuddy, D.J., 2016. Mechanisms of Physical-Biological-Biogeochemical Interaction at the Oceanic Mesoscale. Annu. Rev. Mar. Sci. 8: 125-59. doi: 10.1146/annurevmarine-010814-015606

Ménard, F., Benivary, H.D., Bodin, N., Coffineau, N., Le Loc'h, F., Mison, T., Richard, P., Potier, M., 2014. Stable isotope patterns in micronekton from the Mozambique Channel. Deep-Sea Res II. 100: 153-163. https://doi.org/10.1016/j.dsr2.2013.10.023

Menkes, C.E., Allain, V., Rodier, M., Gallois, F., Lebourges-Dhaussy, A., Hunt, B.P.V., Smeti, H., Pagano, M., Josse, E., Daroux, A., Lehodey, P., Senina, I., Kestenare, E., 
Lorrain, A., Nicol, S., 2015. Seasonal oceanography from physics to micronekton in the south-west Pacific. Deep-Sea Res. II. 113: 125-144. http://dx.doi.org/10.1016/j.dsr2.2014.10.026

Mohn, C., Beckmann, A., 2002. The upper ocean circulation at Great Meteor Seamount. Ocean Dyn. 52: 179-193. https://doi.org/10.1007/s10236-002-0017-4

Nishino, S., Itoh, M., Kawaguchi, Y., Kikuchi, T., Aoyama, M., 2011. Impact of an unusually large warm-core eddy on distributions of nutrients and phytoplankton in the southwestern Canada Basin during late summer/early fall 2010. Geophysical Research Letters. 38: L16602. doi:10.1029/2011GL047885, 2011

Noyon, M., Morris, T., Walker, D., Huggett, J., 2018. Plankton distribution within a young cyclonic eddy off south-western Madagascar. Deep Sea Res. II. In Press. https://doi.org/10.1016/j.dsr2.2018.11.001

Noyon, M., Rasoloarijao, Z., Huggett, J., Ternon, J-F., Roberts, M., 2020. Comparison of mesozooplankton communities at three shallow seamounts in the South West Indian Ocean. Deep Sea Res. Part II. https://doi.org/10.1016/j.dsr2.2020.104759

Ockhuis, S., Huggett, J. A., Gouws, G., Sparks, C., 2017. The 'suitcase hypothesis': Can entrainment of meroplankton by eddies provide a pathway for gene flow between Madagascar and KwaZulu-Natal, South Africa?. African J Mar. Sci. 39(4): 435-451. https://doi.org/10.2989/1814232X.2017.1399292

Ohman, M.D., Frost, B.W., Cohen, E.B., 1983. Reverse Diel Vertical Migration: An Escape from Invertebrate Predators. Science. 220(4604): 1404-1407. DOI: 10.1126/science.220.4604.1404

Okubo, A., 1970. Horizontal dispersion of floatable particles in the vicinity of velocity singularities such as convergences. Deep Sea Res. 17: 445-454.

Owen, R.W., 1980. Eddies of the California Current System: Physical and ecological characteristics, in The California Islands: Proceedings of a Multidisciplinary Symposium, edited by D. Power, 237 - 263. Santa Barbara Mus. of Nat. Hist., Santa Barbara, California.

Owen, R.W., 1981. Fronts and eddies in the sea: mechanisms, interactions, and biological effects.197-233 in Longhurst, A. R., [Ed]. Analysis of marine ecosystems. Academic Press, New York.

Parin, N.V., Prutko, V.G., 1985. Thalassal mesobenthopelagic ichthyocoen over the Equator submarine rise in the western tropical Indian Ocean. Okeanologya 25: 1017-1020 (in Russian).

Perrot Y., Brehmer P., Habasque J., Roudaut G., Béhagle N., Sarre A., Lebourges-Dhaussy A., 2018. Matecho: an open-source tool for processing fisheries acoustics data. Acoustics Australia. 46(2): 241-248. ISSN 1839-2571

Pollard, R., Read, J., 2017. Circulation, stratification and seamounts in the Southwest Indian Ocean. Deep-Sea Res. II. 136: 36-43. https://doi.org/10.1016/j.dsr2.2015.02.018

Porteiro, F.M., Sutton, T., 2007. Midwater Fish Assemblages and Seamounts, in: Pitcher, T.J., Morato, T., Hart, P.J.B., Clark, M.R., Haggan, N., Santos, R.S. (Eds.), Seamounts: Ecology, Fisheries \& Conservation. Blackwell Publishing Ltd, Oxford, UK, pp. 101-116. https://doi.org/10.1002/9780470691953.ch6

Potier, M., Marsac, F., Cherel, Y., Lucas, V., Sabatié, R., Maury, O., Ménard, F., 2007. Forage fauna in the diet of three large pelagic fishes (lancetfish, swordfish and yellowfin tuna) in the western equatorial Indian Ocean. Fisheries Res. 83: 60-72. doi:10.1016/j.fishres.2006.08.020

Pous, S., Lazure, P., André, G., Dumas, F., Halo, I., Penven, P., 2014. Circulation around La Réunion and Mauritius islands in the south-western Indian Ocean: A modeling perspective. J. Geophys. Res. Oceans. 119: 1957-1976. doi:10.1002/2013JC009704 
Pripp, T., Gammelsrød, T., Krakstad, J.O., 2014. Physical influence on biological production along the western shelf of Madagascar. Deep-Sea Res. II. 100: 174-183. http://dx.doi.org/10.1016/j.dsr2.2013.10.025

Proud, R., Handegard, N.O., Kloser, R.J., Cox, M.L., Brierley, A.S., 2018. From siphonophores to deep scattering layers: uncertainty ranges for the estimation of global mesopelagic fish biomass. ICES J. Mar. Sci. fsy037, https://doi.org/10.1093/icesjms/fsy037

Raj, R.P., Peter, B.N., Pushpadas, D., 2010. Oceanic and atmospheric influences on the variability of phytoplankton bloom in the Southwestern Indian Ocean. J. Mar. Syst. 82, 217-229. https://doi.org/10.1016/j.jmarsys.2010.05.009

Ramanantsoa, J.D., Krug, M., Penven, P., Rouault, M., Gula, J., 2018. Coastal upwelling south of Madagascar: Temporal and spatial variability. J. Mar. Sci. 178: 29-37. http://dx.doi.org/10.1016/j.jmarsys.2017.10.005

Royer, T.C., 1978. Ocean Eddies Generated by Seamounts in the North Pacific. Science 199, 1063-1064. https://doi.org/10.1126/science.199.4333.1063-a

Ryan, T.E., Downie, R.A., Kloser, R.J., Keith, G., 2015. Reducing bias due to noise and attenuation in open-ocean echo integration data. ICES J. Mar. Sci. 72(8): 2482-2493. doi:10.1093/icesjms/fsv121

Schlitzer, R., 2013. Ocean Data View, http://odv.awi.de

Singh, A., Gandhi, N., Ramesh, R., Prakash, S., 2015. Role of cyclonic eddy in enhancing primary and new production in the Bay of Bengal. J. Sea Res. 97: 5-13. https://doi.org/10.1016/j.seares.2014.12.002

Torgersen, T., Kaartvedt, S., 2001. In situ swimming behaviour of individual mesopelagic fish studied by split-beam echo target tracking. ICES J. Mar. Sci. 58: 346-354. doi:10.1006/jmsc.2000.1016

Trenkel, V.M., Berger, L., Bourguignon, S., Doray, M., Fablet, R., Massé, J., Mazauric, V., Poncelet, C., Quemener, G., Scalabrin, C., Villalobos, H., 2009. Overview of recent progress in fisheries acoustics made by Ifremer with examples from the Bay of Biscay. Aquat. Living Resour. 22: 433-445. doi: 10.1051/alr/2009027

Vianello, P., Herbette, S., Ternon, J-F., Demarcq, H., Roberts, M., 2020. Circulation and hydrography in the vicinity of a shallow seamount on the northern Madagascar Ridge. Deep Sea Res. Part II.

Watanabe, H., Kawaguchi, K., Hayashi, A., 2002. Feeding habits of juvenile surface migratory myctophid fishes (family Myctophidae) in the Kuroshio region of the western North Pacific. Mar. Ecol. Prog. Ser. 236: 263-272. https://doi.org/10.3354/meps236263

Weiss, J., 1991. The dynamics of enstrophy transfer in two-dimensional hydrodynamics. Physica D: Nonlinear Phenomena. 48: 273-294.

White, M., Bashmachnikov, I., Arstegui, J., Martins, A., 2007. Physical Processes and Seamount Productivity, in: Pitcher, T.J., Morato, T., Hart, P.J.B., Clark, M.R., Haggan, N., Santos, R.S. (Eds.), Seamounts: Ecology, Fisheries \& Conservation. Blackwell Publishing Ltd, Oxford, UK, pp. 62-84. https://doi.org/10.1002/9780470691953.ch4

Wilson, C.D., Boehlert, G.W., 2004. Interaction of ocean currents and resident micronekton at a seamount in the central North Pacific. J. Mar. Syst. 50: 39-60. https://doi.org/10.1016/j.jmarsys.2003.09.013 
Figure 1(a) Map of MAD-Ridge and La Pérouse CTD stations (diamond symbols) conducted in the East African Coastal (EAFR) and Indian South Subtropical Gyre (ISSG) provinces respectively. Longhurst's (2007) biogeochemical provinces are delimited by black solid lines. Landmasses are shown in grey and seamount summits in red. (b) La Pérouse CTD stations are plotted on the bathymetry $(\mathrm{m})$. The colour bar represents the depth $(\mathrm{m})$ below the sea surface.

Figure 2 Satellite surface absolute dynamic height (m) on 19 November 2016 during MADRidge cruise. Geostrophic velocity vectors $\left(\mathrm{m} \mathrm{s}^{-1}\right)$ (black arrows) and the position of CTD stations numbered 1-31 (grey dots) are superimposed along the West-East (W-E) and SouthNorth (S-N) transects. Madagascan landmass is shown in orange.

Figure 3 Vertical distributions of (a) current speed $\left(\mathrm{cm} \mathrm{s}^{-1}\right)$, (b) temperature $\left({ }^{\circ} \mathrm{C}\right)$, and (c) chlorophyll $a\left(\mathrm{mg} \mathrm{m}^{-3}\right)$ for MAD-Ridge Leg 1 West-East transect (CTD stations labelled 115, left panels) across the cyclonic (C) and anticyclonic (AC) eddies, and South-North transect (CTD stations labelled 16-31, right panels) across the anticyclonic eddy and shelf (Sf). The MAD-Ridge seamount and the Madagascan shelf are shown in grey.

Figure 4 West-East (W-E) transect of MAD-Ridge: Mean micronekton acoustic density $\left(\mathrm{s}_{\mathrm{A}}\right.$, $\mathrm{m}^{2} \mathrm{nmi}^{-2}$ ) from Day_I to Day_V and Night_I to Night_IV: grey for surface layer $(10-200 \mathrm{~m})$, white for intermediate layer (200-400 m) and black for deep layer (400-735 m). Stacked bars are labelled: C (Cyclonic), C/D.I (Cyclonic/Dipole Interface), S/AC (Summit/ Anticyclonic), AC (Anticyclonic), AC/P (Anticyclonic/ Eddy periphery) and D.I (Dipole Interface).

Figure 5 Echogram of the $38 \mathrm{kHz}$ frequency across CTD stations 6-8 (denoted by striped bars). Deep topographic features $\mathrm{X}$ and $\mathrm{Y}$ and MAD-Ridge seamount are labelled in red. Periods corresponding to sunset, night, sunrise and day are denoted by red, blue, violet and gold horizontal rectangles, respectively. Colour bar indicates $\mathrm{s}_{\mathrm{A}}$ in $\mathrm{m}^{2} \mathrm{nmi}^{-2}$.

Figure 6 RGB composite images of $S_{V}$ values ( $\mathrm{dB}$ re $1 \mathrm{~m}^{-1}$ ) across cyclonic CTD stations 2-3 and 4 and anticyclonic stations 10-12 and stations 13-15 (denoted by striped bars). The 38, 70 and $120 \mathrm{kHz}$ frequencies were given red, green and blue colour codes, respectively, as explained in the methods. Periods corresponding to sunset, night, sunrise and day are denoted by red, blue, violet and gold horizontal rectangles, respectively.

Figure 7 South-North (S-N) transect of MAD-Ridge: Mean micronekton acoustic density $\left(\mathrm{s}_{\mathrm{A}}\right.$, $\mathrm{m}^{2} \mathrm{nmi}^{-2}$ ) from Day_VI to Day_X and Night_VI to Night_IX: grey for surface layer (10-200 $\mathrm{m})$, white for intermediate layer (200-400 m) and black for deep layer (400-735 m). Stacked bars are labelled: AC (Anticyclonic), AC/F/S (Anticyclonic/Flank/Summit), S/F/AC (Summit/Flank/Anticyclonic), AC/P (Anticyclonic/Eddy periphery) and AC.P/S (Anticyclonic eddy periphery and shelf), S/AC (Summit/Anticyclonic) and AC.P (Anticyclonic eddy periphery).

Figure 8 RGB composite images of $S_{V}$ values ( $\mathrm{dB}$ re $1 \mathrm{~m}^{-1}$ ) at anticyclonic CTD stations 2123 and shelf stations 30-31 (labelled by striped bars). The 38, 70 and $120 \mathrm{kHz}$ frequencies were given red, green and blue colour codes respectively. Periods corresponding to sunset, night, sunrise and day are denoted by red, blue, violet and gold horizontal rectangles, respectively. 
Figure 9(a) Boxplots of total micronekton acoustic densities $\left(\mathrm{s}_{\mathrm{A}}, \mathrm{m}^{2} \mathrm{nmi}^{-2}\right)$ of the $38 \mathrm{kHz}$ frequency in the deep $(400-735 \mathrm{~m})$, intermediate $(200-400 \mathrm{~m})$, surface layers $(10-200 \mathrm{~m})$ and total water column $(10-735 \mathrm{~m}$ ) for the transects at CTD stations: 10-13, 16-19, 24, 25 (AC: anticyclonic); 2, 3, 4 (C: cyclonic); 5 (Dipole Interface); 7, 9, 20, 23 (Flank/AC); 30, 31 (Shelf); and 8, 21, 22 (Summit/AC) of the MAD-Ridge cruise. Mean and standard deviations of the variables (b) SLA (m), (c) Temperature at 100 m, (d) Fmax depth (m), (e) integrated chlorophyll $a$ between $2-200 \mathrm{~m}\left(\mathrm{mg} \mathrm{m}^{-3}\right)$, and (f) zooplankton biovolume $\left(\mathrm{mm}^{3} \mathrm{~m}^{-3}\right)$ are plotted for the AC, C, Dipole I., Flank/AC, Shelf and Summit/AC stations.

Figure 10 Satellite surface absolute dynamic height (m) on 16 September 2016 during the La Pérouse cruise showing La Pérouse seamount (black star). Geostrophic velocity vectors ( $\mathrm{m} \mathrm{s}^{-}$ ${ }^{1}$ ) (black arrows) are superimposed. Réunion landmass is shown in orange.

Figure 11 Map of La Pérouse and MAD-Ridge, daytime (yellow lines) and night-time (blue lines) acoustic transects plotted on the bathymetry. Colour bar indicates bathymetry $(\mathrm{m})$ and the scale bar is given. Bar charts of mean micronekton acoustic densities $\left(\mathrm{s}_{\mathrm{A}}, \mathrm{m}^{2} \mathrm{nmi}^{-2}\right) \pm$ standard deviations during the day and night: grey for surface layer $(10-200 \mathrm{~m})$, white for intermediate layer (200-400 m) and black for deep layer (400-735 m) at (a) La Pérouse and (b) MAD-Ridge.

Figure 12 RGB composite images of $\mathrm{S}_{\mathrm{V}}$ values $\left(\mathrm{dB}\right.$ re $1 \mathrm{~m}^{-1}$ ) of (a) La Pérouse day, (b) MAD-Ridge day, (c) La Pérouse night and (d) MAD-Ridge night. The MAD-Ridge and La Pérouse summits are shown in black. The 38, 70 and $120 \mathrm{kHz}$ frequencies were given red, green and blue colour codes, respectively. Regions of high $\mathrm{S}_{\mathrm{V}}$ are denoted by "white patches" on the RGB composites. 
Table 1 List of MAD-Ridge Leg 1 classified hydrographic stations: UN for unresolved;

C for Cyclonic; D.I for Dipole Interface; AC for Anticyclonic; S for summit; F for flank; Sf for Shelf.

\begin{tabular}{|c|c|c|c|c|c|c|c|c|c|}
\hline $\begin{array}{l}\text { Station } \\
\text { Number }\end{array}$ & $\begin{array}{l}\text { Day/ } \\
\text { Sunset }\end{array}$ & $\begin{array}{l}\text { ADT } \\
\text { (m) }\end{array}$ & $\begin{array}{l}\text { MSLA } \\
\text { (m) }\end{array}$ & $\begin{array}{l}\text { Vorticity } \\
\left(\mathrm{s}^{-1}\right)\end{array}$ & $\begin{array}{l}\text { Okubo-Weiss } \\
\left(\mathrm{s}^{-2}\right)\end{array}$ & $\begin{array}{l}\text { Temper- } \\
\text { ature }\left({ }^{\circ} \mathbf{S}\right) \\
\text { TSG }\end{array}$ & $\begin{array}{l}\text { Salinity } \\
\text { (PSU) } \\
\text { TSG }\end{array}$ & $\begin{array}{l}\text { Sea floor } \\
\text { Depth } \\
\text { (m) }\end{array}$ & $\begin{array}{l}\text { Classifi- } \\
\text { cations }\end{array}$ \\
\hline 1 & Day & 0.89 & -0.19 & $-1.21 \mathrm{E}-05$ & $1.63 \mathrm{E}-11$ & 23.68 & 35.36 & 1573 & UN \\
\hline 2 & Day & 0.82 & -0.27 & $-1.97 \mathrm{E}-05$ & $5.00 \mathrm{E}-11$ & 23.92 & 35.36 & 1930 & $\mathrm{C}$ \\
\hline 3 & Sunset & 0.84 & -0.25 & $-2.94 \mathrm{E}-05$ & $-5.32 \mathrm{E}-10$ & 23.89 & 35.38 & 1630 & $\mathrm{C}$ \\
\hline 4 & Day & 0.96 & -0.15 & $-1.50 \mathrm{E}-05$ & $-4.97 \mathrm{E}-10$ & 23.72 & 35.30 & 1730 & $\mathrm{C}$ \\
\hline 5 & Day & 1.08 & -0.03 & $-5.80 \mathrm{E}-07$ & $1.02 \mathrm{E}-10$ & 24.37 & 35.14 & 1460 & D.I \\
\hline 6 & Day & 1.21 & 0.10 & $1.49 \mathrm{E}-05$ & $6.14 \mathrm{E}-11$ & 24.71 & 35.18 & 1760 & UN \\
\hline 7 & Day & 1.30 & 0.20 & $2.86 \mathrm{E}-05$ & $-3.34 \mathrm{E}-10$ & 24.40 & 35.21 & 670 & F/AC \\
\hline 8 & Day & 1.33 & 0.23 & $3.15 \mathrm{E}-05$ & $-4.92 \mathrm{E}-10$ & 24.39 & 35.22 & 240 & $\mathrm{~S} / \mathrm{AC}$ \\
\hline 9 & Day & 1.36 & 0.25 & $3.14 \mathrm{E}-05$ & $-5.33 \mathrm{E}-10$ & 24.33 & 35.22 & 645 & F/AC \\
\hline 10 & Day & 1.42 & 0.32 & $3.01 \mathrm{E}-05$ & $-5.85 \mathrm{E}-10$ & 24.31 & 35.28 & 1600 & $\mathrm{AC}$ \\
\hline 11 & Day & 1.46 & 0.36 & $2.86 \mathrm{E}-05$ & $-6.71 \mathrm{E}-10$ & 24.49 & 35.28 & 1733 & $\mathrm{AC}$ \\
\hline 12 & Day & 1.45 & 0.37 & $2.54 \mathrm{E}-05$ & $-5.62 \mathrm{E}-10$ & 24.55 & 35.29 & 1585 & $\mathrm{AC}$ \\
\hline 13 & Day & 1.41 & 0.35 & $2.55 \mathrm{E}-05$ & $-6.09 \mathrm{E}-10$ & 24.42 & 35.28 & 1505 & $\mathrm{AC}$ \\
\hline 14 & Day & 1.31 & 0.27 & $1.81 \mathrm{E}-05$ & $-3.23 \mathrm{E}-10$ & 24.40 & 35.23 & 1964 & UN \\
\hline 15 & Day & 1.18 & 0.16 & $6.75 \mathrm{E}-07$ & $7.35 \mathrm{E}-11$ & 24.79 & 35.28 & 2110 & UN \\
\hline 16 & Day & 1.25 & 0.22 & $1.94 \mathrm{E}-05$ & $-2.80 \mathrm{E}-10$ & 24.25 & 35.21 & 1927 & $\mathrm{AC}$ \\
\hline 17 & Day & 1.34 & 0.28 & $1.95 \mathrm{E}-05$ & $-2.20 \mathrm{E}-10$ & 24.57 & 35.29 & 2380 & $\mathrm{AC}$ \\
\hline 18 & Sunset & 1.41 & 0.32 & $2.44 \mathrm{E}-05$ & $-3.40 \mathrm{E}-10$ & 24.58 & 35.28 & 1674 & $\mathrm{AC}$ \\
\hline 19 & Day & 1.43 & 0.33 & $2.69 \mathrm{E}-05$ & $-4.79 \mathrm{E}-10$ & 24.38 & 35.22 & 1668 & $\mathrm{AC}$ \\
\hline 20 & Day & 1.41 & 0.31 & $2.76 \mathrm{E}-05$ & $-4.98 \mathrm{E}-10$ & 24.65 & 35.23 & 720 & $\mathrm{~F} / \mathrm{AC}$ \\
\hline 21 & Day & 1.4 & 0.30 & $2.77 \mathrm{E}-05$ & $-5.06 \mathrm{E}-10$ & 24.84 & 35.24 & 257 & $\mathrm{~S} / \mathrm{AC}$ \\
\hline 22 & Day & 1.41 & 0.30 & $2.63 \mathrm{E}-05$ & $-4.58 \mathrm{E}-10$ & 24.40 & 35.24 & 255 & $\mathrm{~S} / \mathrm{AC}$ \\
\hline 23 & Day & 1.41 & 0.30 & $2.58 \mathrm{E}-05$ & $-4.32 \mathrm{E}-10$ & 24.77 & 35.24 & 621 & F/AC \\
\hline 24 & Day & 1.4 & 0.28 & $2.42 \mathrm{E}-05$ & $-3.50 \mathrm{E}-10$ & 24.77 & 35.24 & 1502 & $\mathrm{AC}$ \\
\hline 25 & Day & 1.38 & 0.27 & $2.22 \mathrm{E}-05$ & $-2.12 \mathrm{E}-10$ & 24.77 & 35.24 & 1585 & $\mathrm{AC}$ \\
\hline 26 & Day & 1.32 & 0.22 & $1.50 \mathrm{E}-05$ & $1.14 \mathrm{E}-11$ & 24.46 & 35.14 & 1747 & $\mathrm{UN}$ \\
\hline 27 & Day & 1.25 & 0.20 & $8.21 \mathrm{E}-06$ & $1.09 \mathrm{E}-12$ & 24.46 & 35.14 & 1916 & UN \\
\hline 28 & Day & 1.21 & 0.23 & $9.75 \mathrm{E}-06$ & $-9.40 \mathrm{E}-11$ & 24.47 & 35.14 & 2125 & UN \\
\hline 29 & Day & 1.11 & 0.23 & $2.25 \mathrm{E}-06$ & $3.08 \mathrm{E}-11$ & 24.73 & 35.15 & 1875 & UN \\
\hline 30 & Day & 1.00 & 0.21 & $-7.82 \mathrm{E}-06$ & $7.21 \mathrm{E}-11$ & 24.77 & 35.21 & 1436 & Sf \\
\hline 31 & Sunset & 0.95 & 0.19 & $-7.39 \mathrm{E}-06$ & $1.82 \mathrm{E}-10$ & 24.68 & 35.30 & 840 & $\mathrm{Sf}$ \\
\hline
\end{tabular}


a)

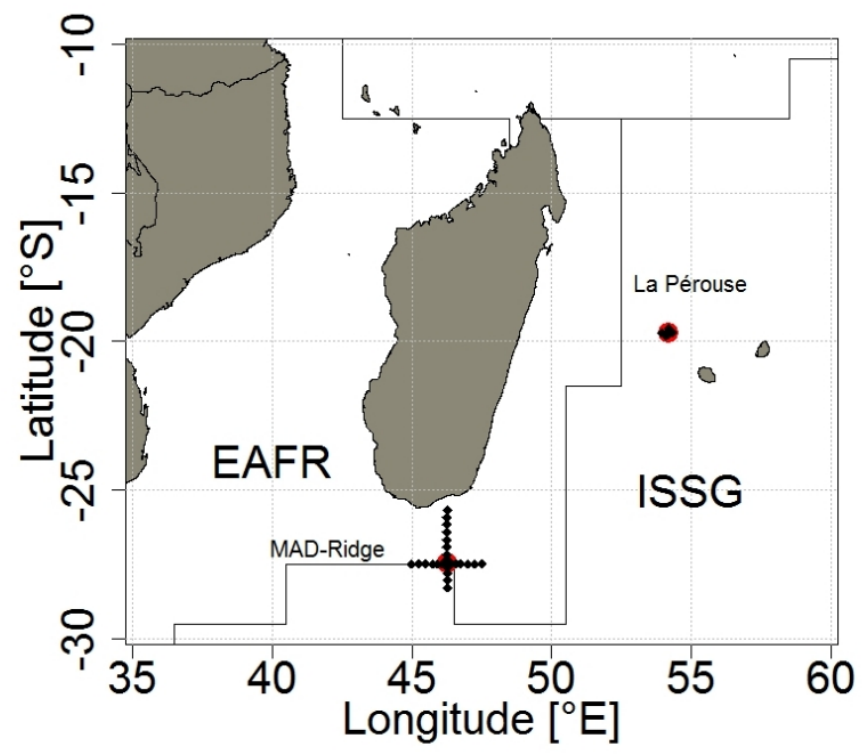

b)

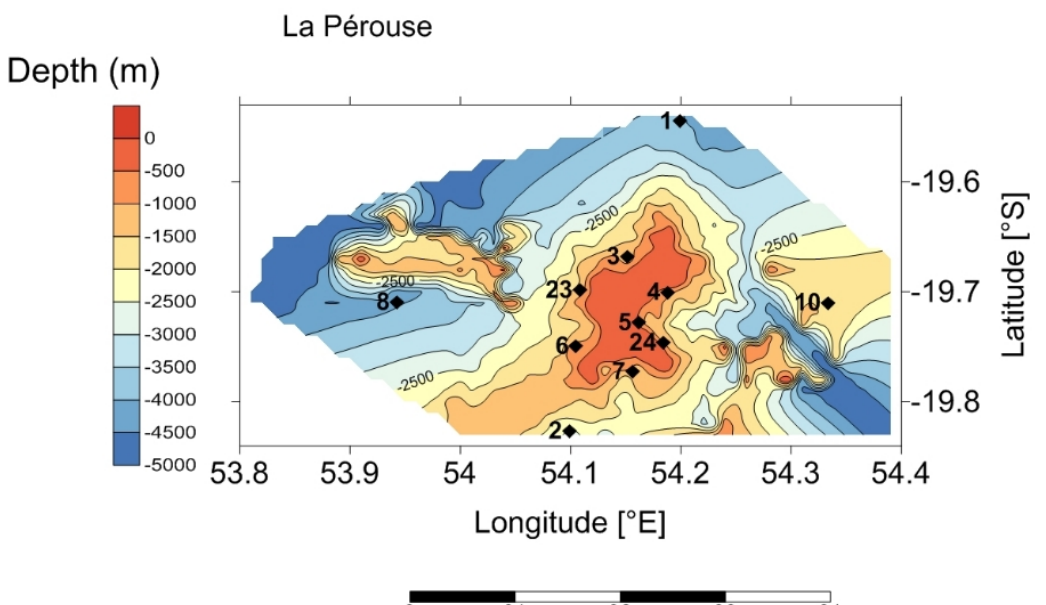

Figure 1 


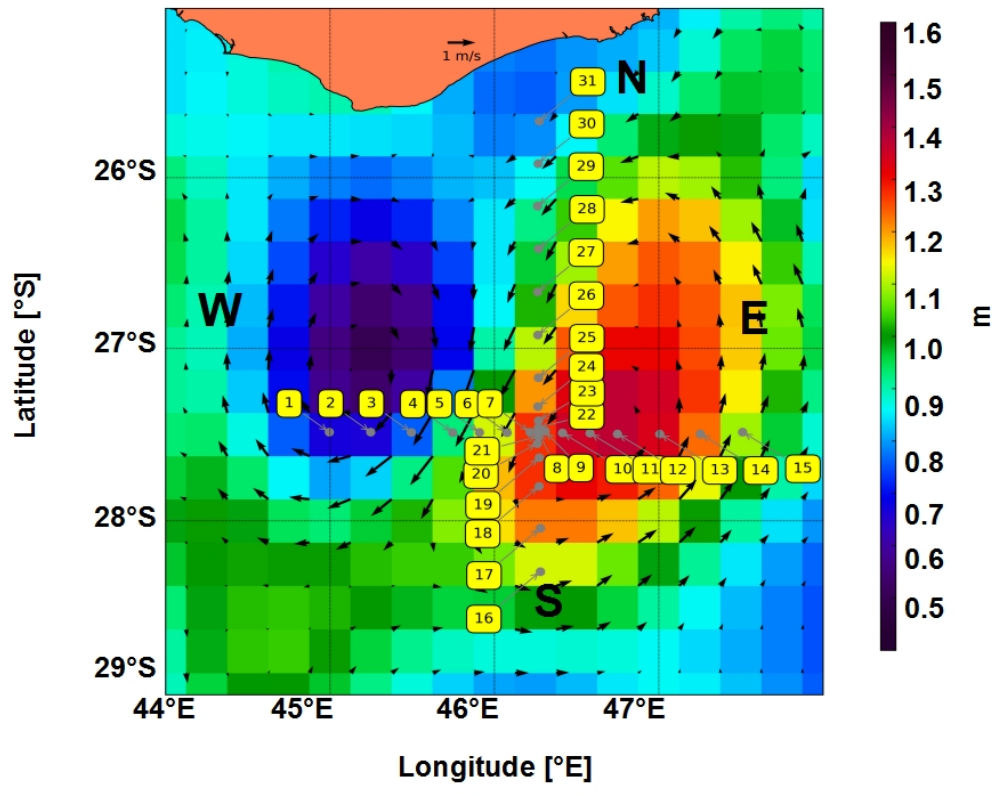

Figure 2 


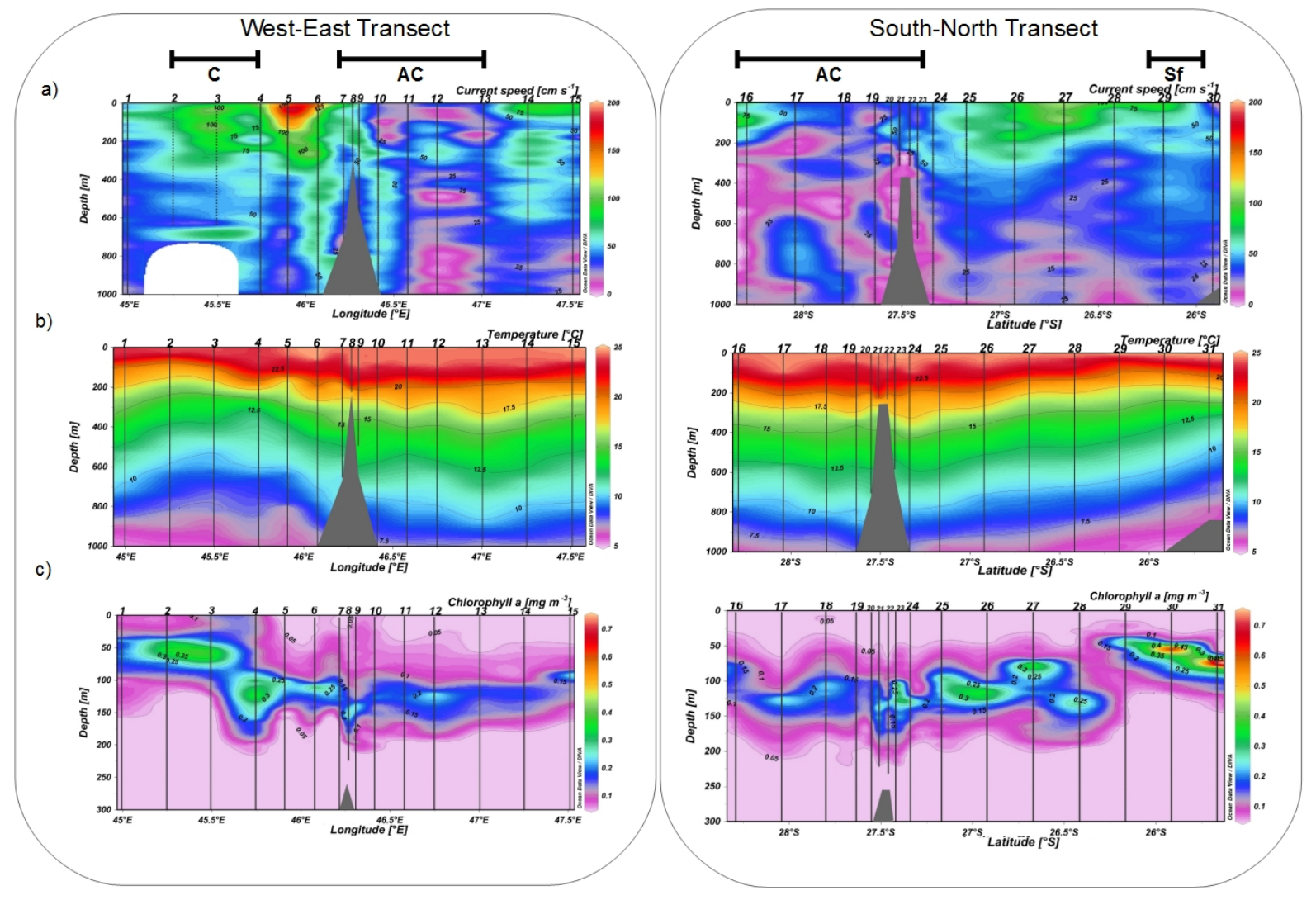

Figure 3 


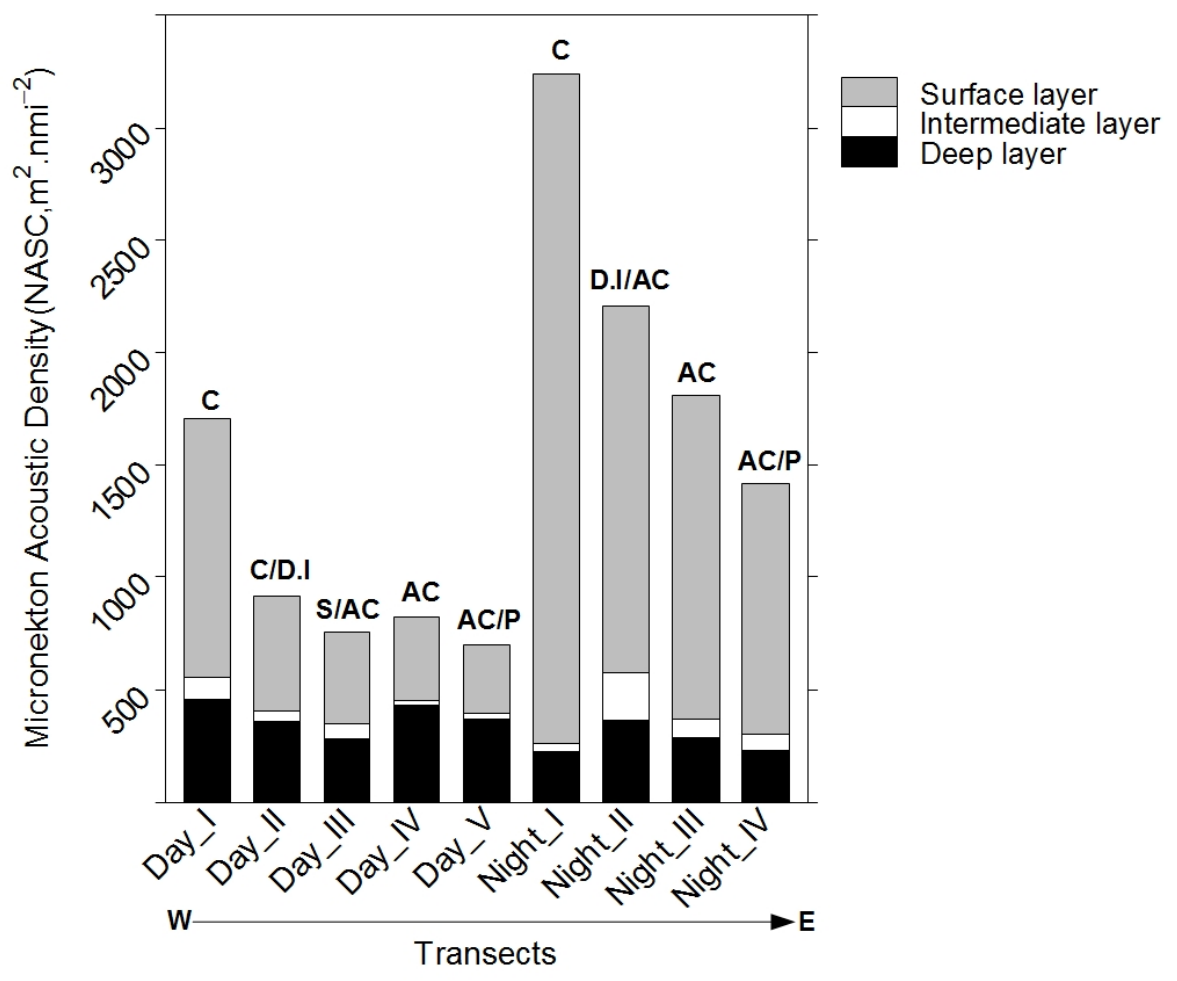

Figure 4 


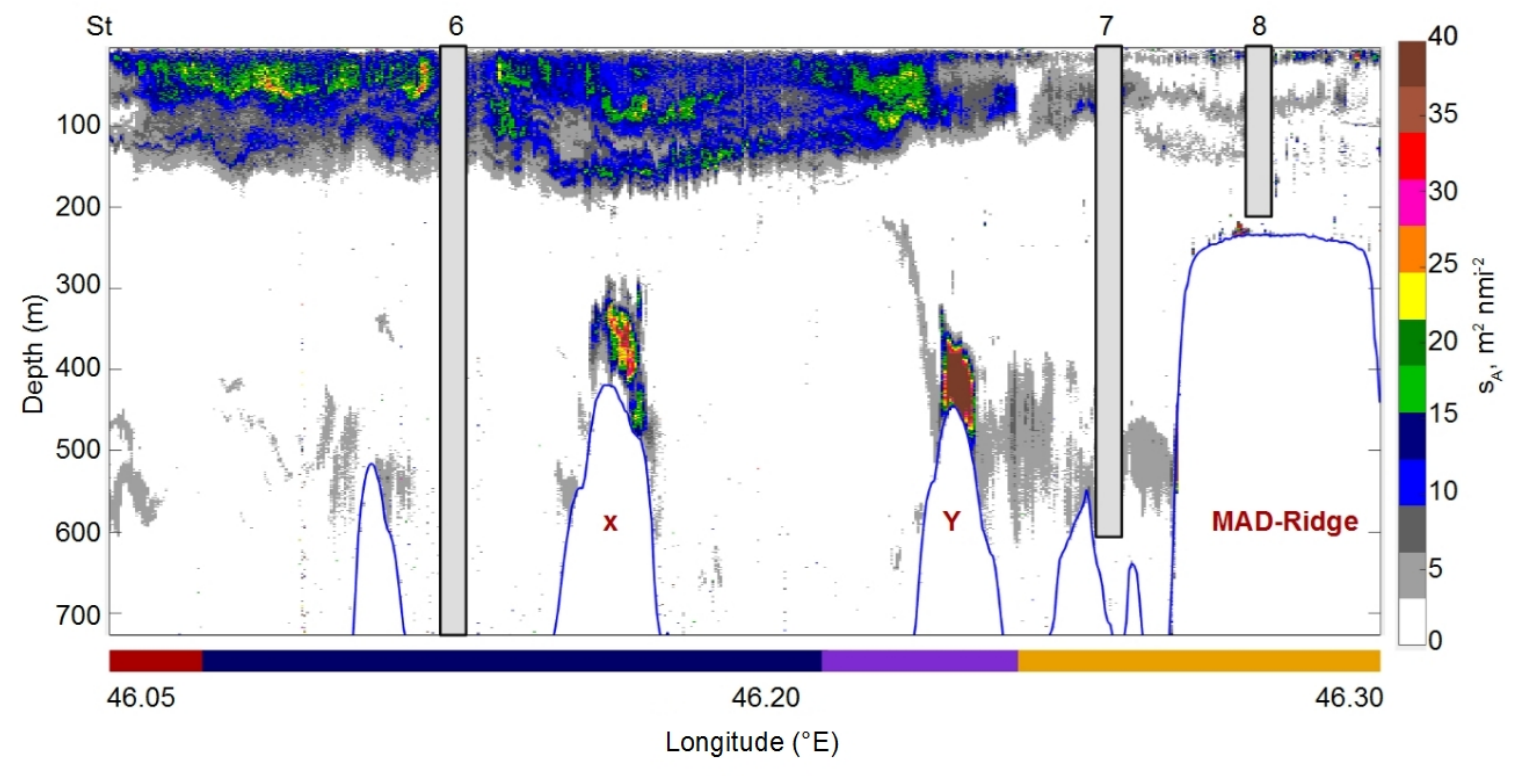

Figure 5 
Red: Sv 38 kHz; Green: Sv 70 kHz; Blue: Sv 120 kHz
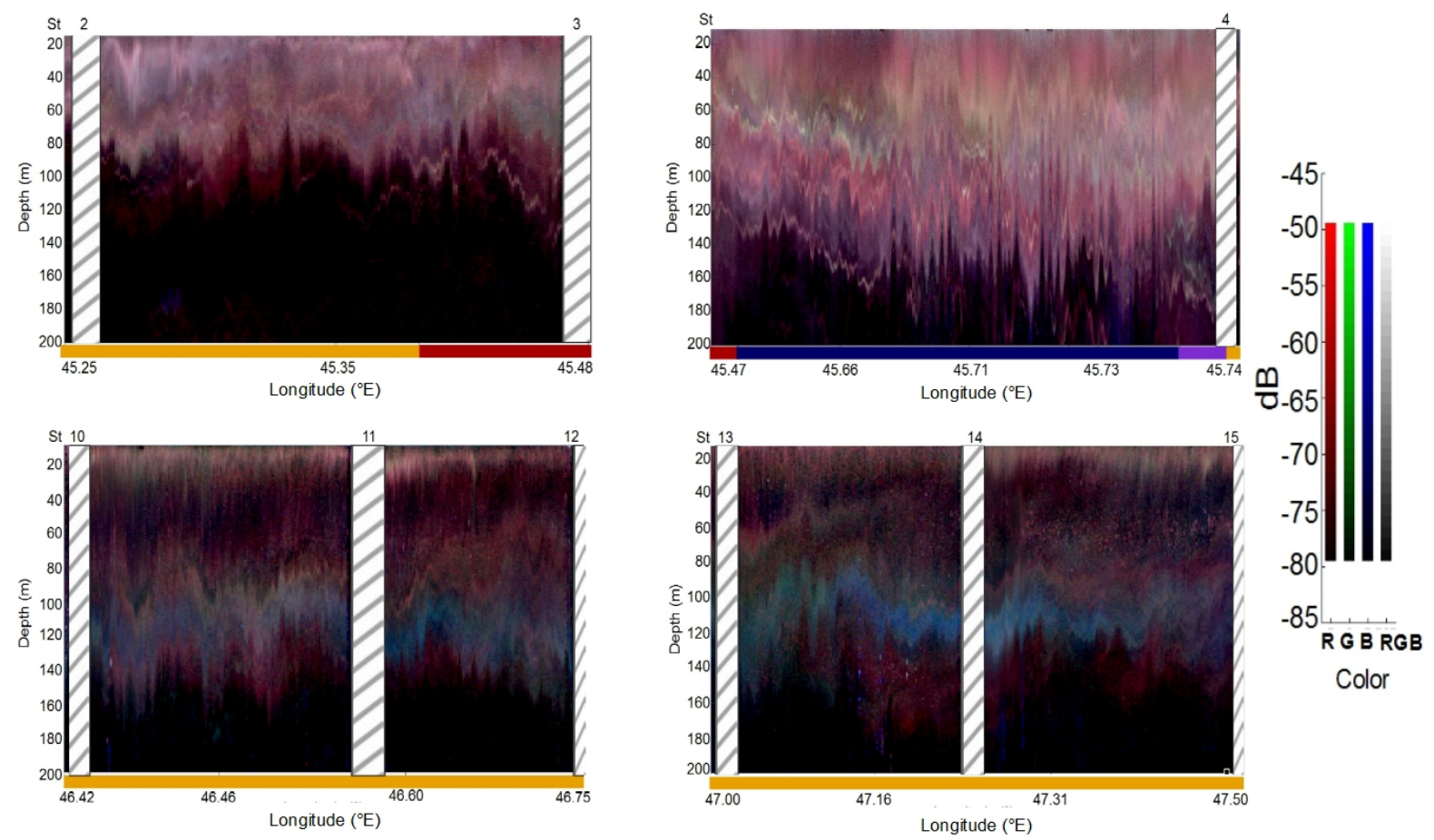

Figure 6 


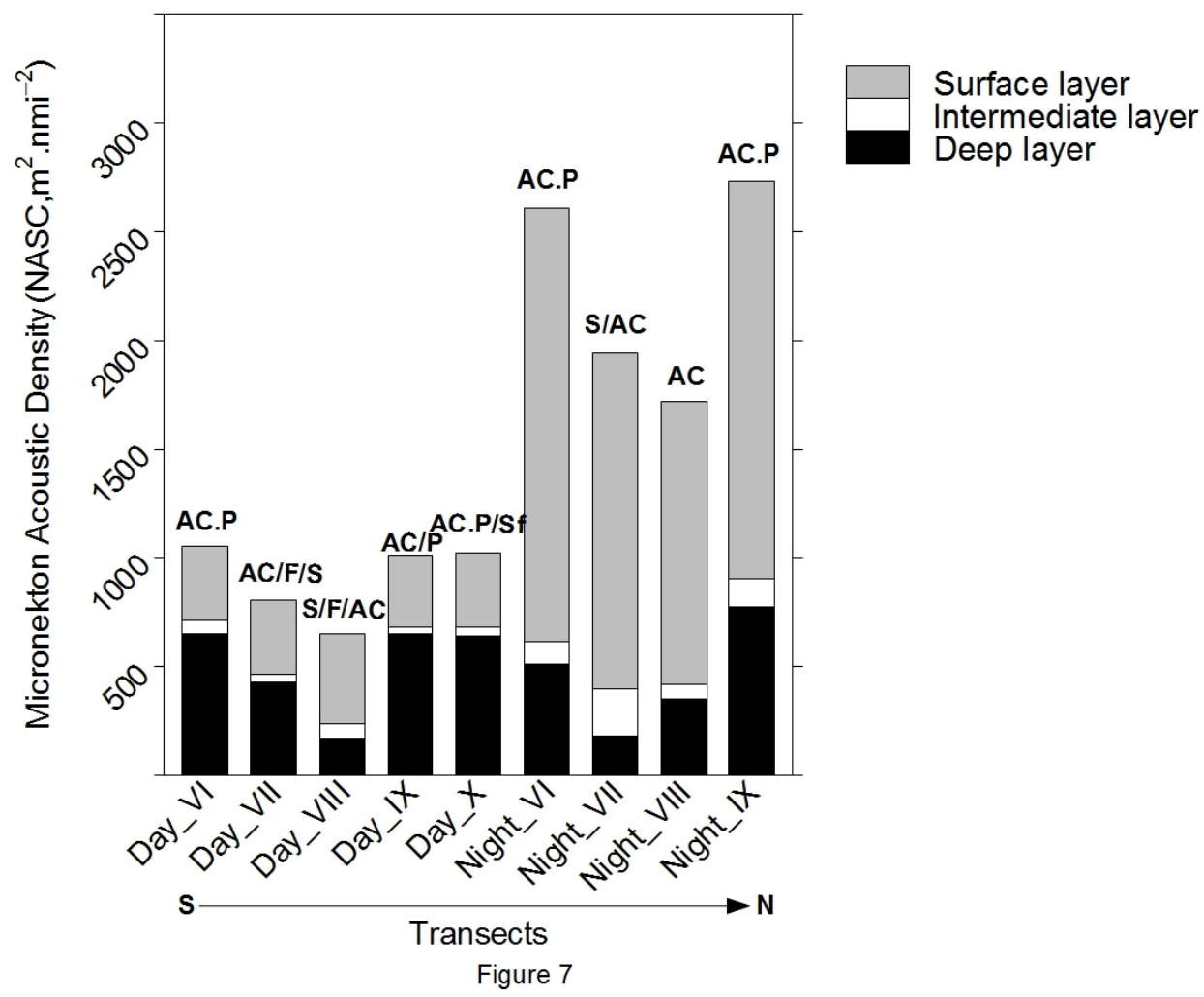


Red: Sv 38 kHz; Green: Sv 70 kHz; Blue: Sv 120 kHz
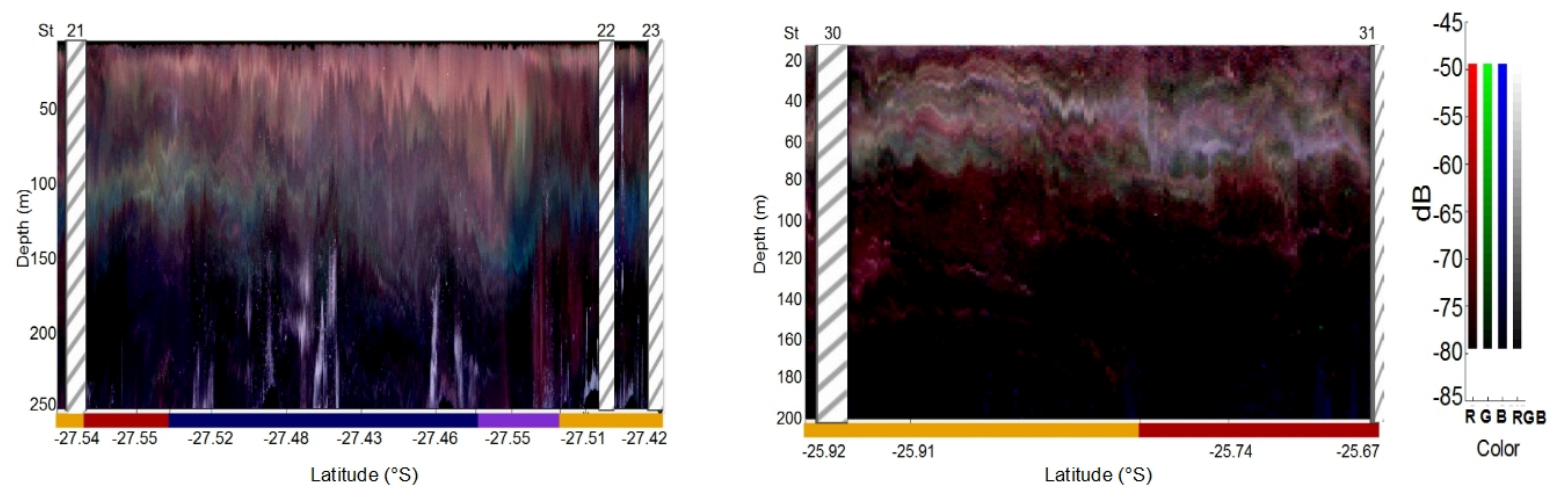

Figure 8 
a)

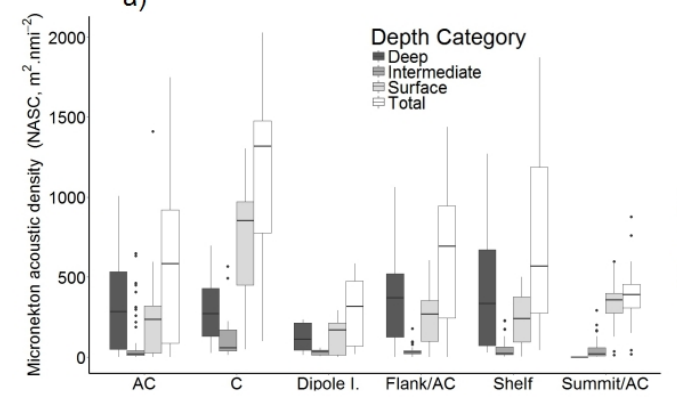

b)

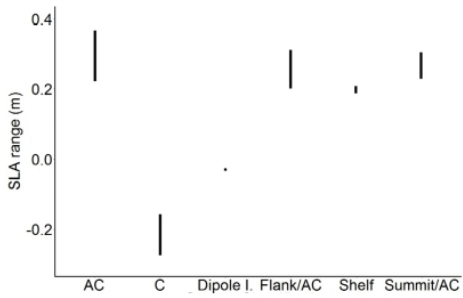

c)

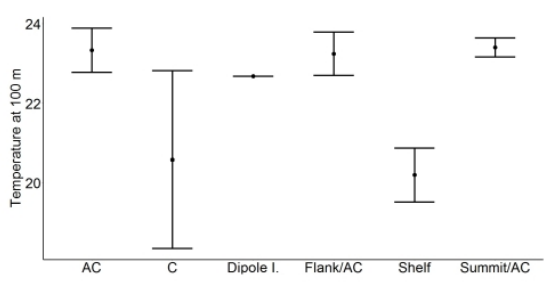

d)

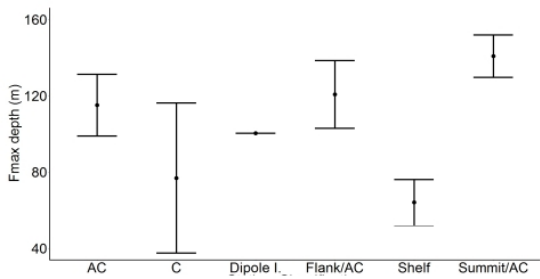

f)

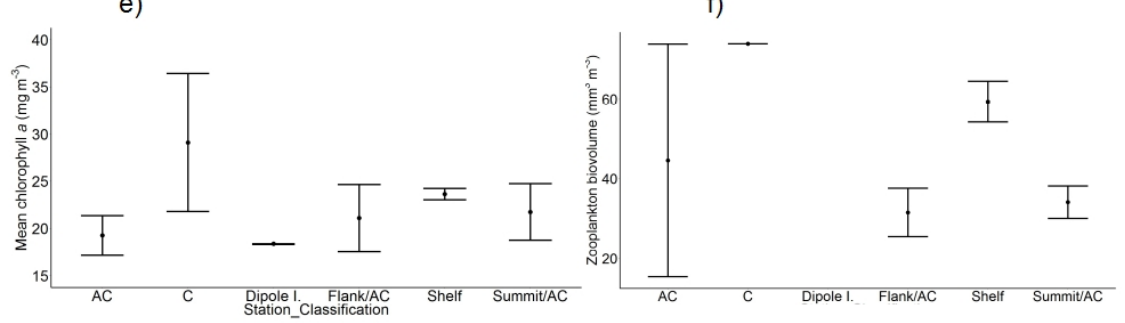

Figure 9 


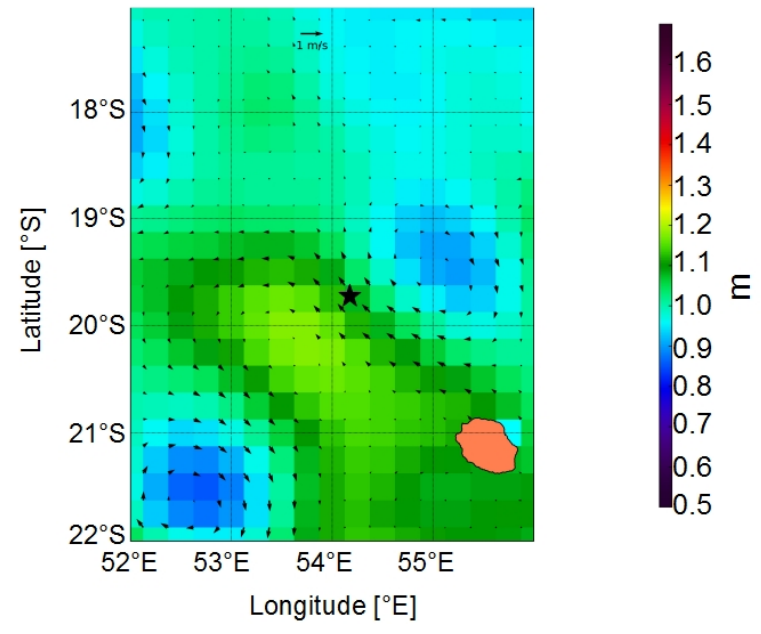

Figure 10 

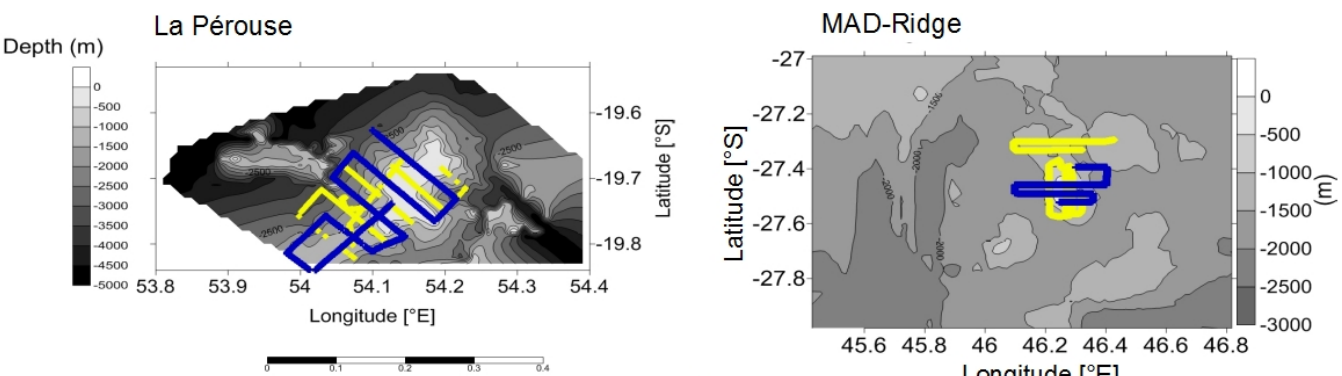

(a)

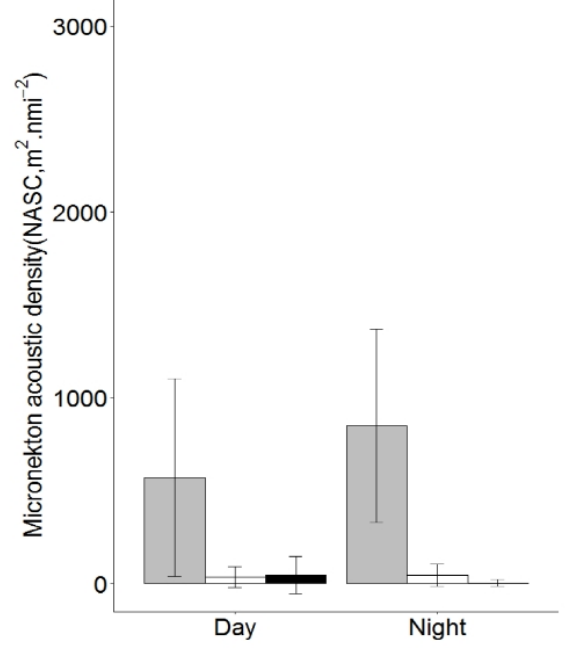

(b)

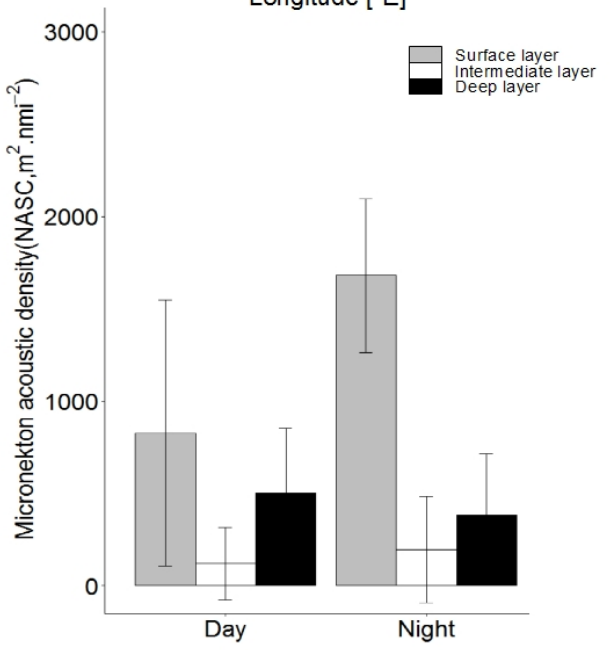

Figure 11 
Red: 38 kHz; Green: 70 kHz; Blue: 120 kHz

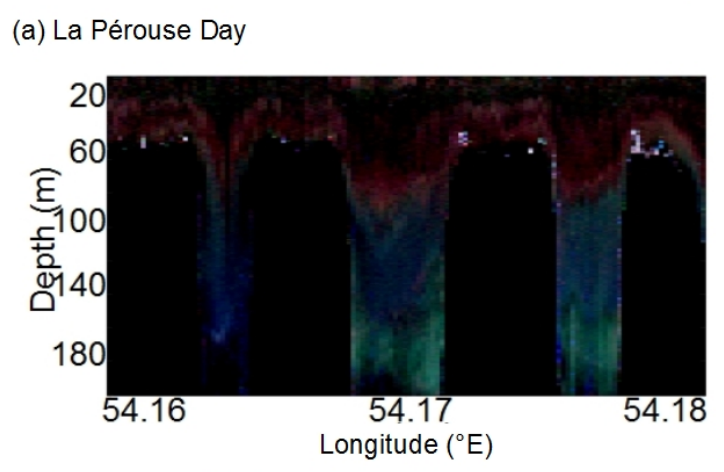

(c) La Pérouse Night

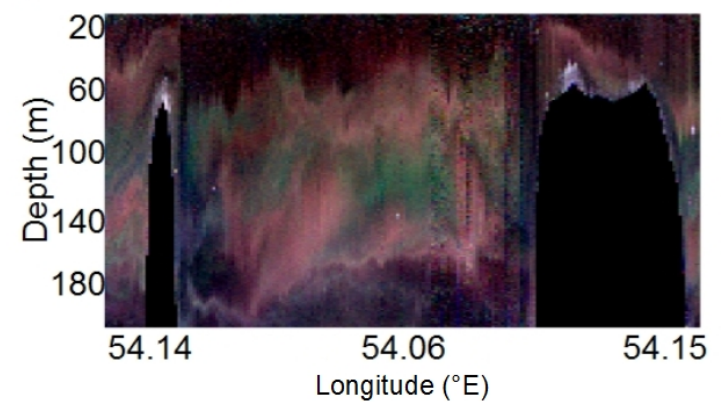

(b) MAD-Ridge Day

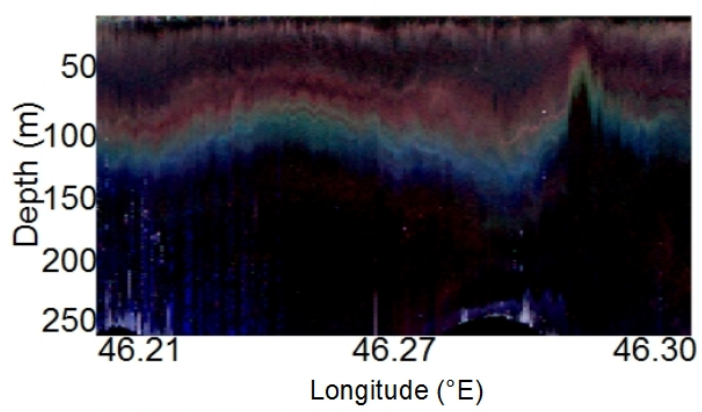

(d) MAD-Ridge Night

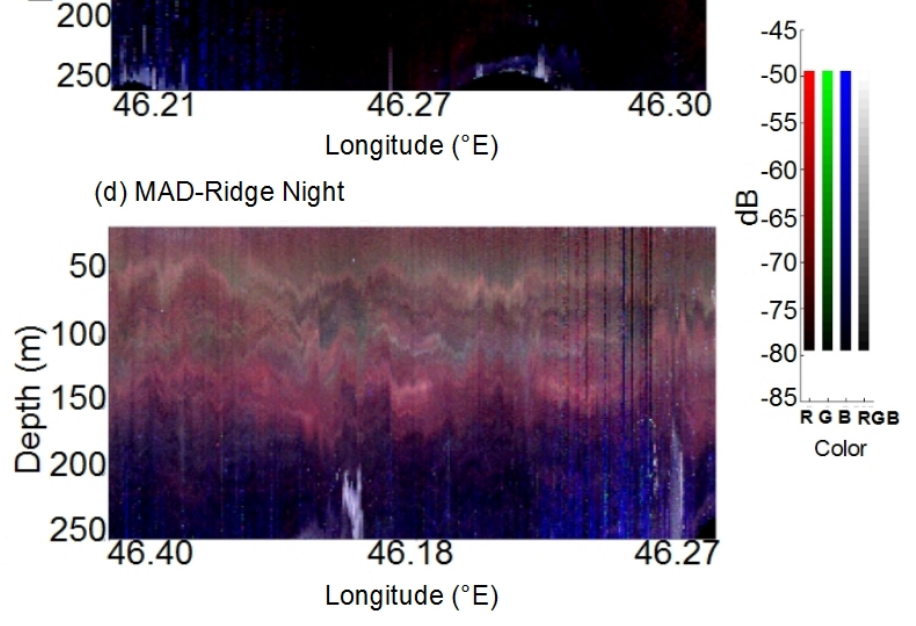

Figure 12 